\title{
Better Opportunities or Worse? The Demise of Cotton Harvest Labor, 1949-1964
}

\author{
Wayne A. Grove And CRAig HeInicke
}

Following World War II millions of cotton workers, especially African-Americans, left the fields forever, and farmers mechanized the cotton harvest. Prevailing empirical studies argue that high factory wages lured farmhands away. Based on newly reconstructed data, we estimate the causes of the demise of harvest employment in 12 major cotton-producing states from 1949-1964 and find important roles for mechanization, government farm programs, higher nonagricultural wages, and falling cotton prices. On net, our estimates indicate that factors affecting farm labor demand, not labor-supply influences, caused the disappearance of hand-picked cotton - results that reverse the best econometric work to date.

"I didn't stay out on that farm too long after they started usin' the cotton pickers and whatnot. That was the time we was told to leave the farm."

Mae Bertha Carter $^{1}$

$\mathrm{I}^{\mathrm{n}}$

$n$ the decades following World War II, cotton ceased to be harvested by hand, millions of workers left the cotton fields forever, and growers who stayed with cotton replaced field labor, hoes, and picking sacks with machines and chemicals. This socioeconomic transformation, which swept away a southern way of life in place for generations, has been intricately linked to fundamental changes in the nation's political economy, race relations, and urban life. Lee Alston and Joe Ferrie connect these changes to the rise of the federal welfare state against which southern rural landed elites withheld their veto only when mechanization eliminated their desire for a pool of cheap field labor. ${ }^{2}$ The mass out-migration of African-Americans from the South, which had begun earlier in the century and accelerated after 1940, converted race relations and racial economic equality from a southern

The Journal of Economic History, Vol. 63, No. 3 (Sept. 2003). (C) The Economic History Association. All rights reserved. ISSN 0022-0507.

Wayne A. Grove is Assistant Professor, Economics Department, LeMoyne College, 1419 Salt Springs Road, Syracuse, NY 13214. E-mail: grovewa@lemoyne.edu. Craig Heinicke is Professor, Economics Department, Baldwin-Wallace College, Berea, OH 44017-2088.E-mail: cheinick@bw.edu.

For helpful comments, we thank Lee Alston, Larry Neal, Werner Baer, Bill Collins, Lee Craig, Carl Moody, Beverley Peart, Eric Hilt, Michele Knapp, the participants of the workshops at Syracuse University, Northwestern University, the University of Illinois, Colby College, Harvard University, the All-Ohio Economic History Seminar (Ohio State University Economics Department), the Social Science History Association Meeting (2001), and the Allied Social Science Meeting (2002), anonymous referees and the editor, Gavin Wright. The authors assume full responsibility for errors and omissions.

${ }^{1}$ Audio from "Goin' to Chicago" by George King and Associates.

${ }^{2}$ Alston and Ferrie, "Paternalism" and Southern Paternalism. 
matter into one of national public interest. Whereas John Donahue and James Heckman emphasize the "episodic" narrowing of the white-black wage gap that coincides in part with the period of interest here, Robert Fairlie and Bill Sundstrom identify an emerging and widening of the racial unemployment gap. ${ }^{3}$ David Cutler, Edward Glaeser, and Jacob Vigdor find that segregation and the spread of ghettos in America's cities increased significantly with post-World War II migration from the rural South, exacerbating the already poor urban educational, employment, and housing opportunities. ${ }^{4}$

Ironically, we know a lot about the consequences of this episode of demographic dislocation but little about what caused the demise of the cotton harvest work force with which much of it was entangled. Richard Day concluded in 1967 that mechanization "pushed" workers in the Yazoo-Mississippi Delta area out of cotton - a finding which Gavin Wright in Old South, New South, and others, generalized to the entire cotton belt and which represents the conventional wisdom among scholars. ${ }^{5}$ Noting that Day's results applied to an important but unrepresentative production zone, Willis Peterson and Yoav Kislev in this JOURNAL offered the first empirical investigation of the transcontinental cotton hand harvest labor market. They found that high manufacturing wages drew workers from the fields, which shifted the cotton harvest labor supply leftward, forming the primary impetus for reduced labor (79 percent) rather than technological displacement (21 percent). ${ }^{6}$ This conclusion that workers left the fields for better opportunities

\footnotetext{
${ }^{3}$ Donahue and Heckman, "Continuous Versus Episodic"; Fairlie and Sundstrom, "Emergence, Persistence"; and Smith and Welch, "Black Economic Progress." Heckman, "Central Role," focusing on the post-1965 period, notes that little progress occurred within regions before 1965 (see also Smith and Welch, "Black Economic Progress," p. 547). This is consistent with our findings. On "wage compression," its effect on the wage gap, and its reversal, see Maloney, "Wage Compression"; and Margo, "Explaining Black-White Wage Convergence."

${ }^{4}$ Cutler et al., "Rise," p. 469. Regarding the role of southern out-migration and urban deterioration, also see Lemann, Promised Land; Wilson, Truly Disadvantaged; and Sugrue, Origins. Margo, Race, emphasized schooling as a long-run cause of migration. On the timing of migration, see Heinicke, "Black Migration"; Johnson and Campbell, Black Migration; and Collins, "When the Tide." Fogel raises the general matter of worker redundancy and technological change in agriculture over three centuries of European development in Fourth Great Awakening, pp. 52-54.

${ }^{5}$ See Day, "Economics." Wright (Old South, p. 245) argued that the labor market moved from "a decade of 'pull' [in the 1940s] to a decade of 'push"' from the fields in the 1950s. For the predominance of harvest mechanization in the decline of hand-harvested cotton, also see Daniel, Breaking the Land, pp. 245, 249; Kirby, Rural Worlds, p. 68; Cobb, Most Southern Place, pp. 205, 255; Fusfeld and Bates, Political Economy; Dillingham and Sly, "Mechanical Cotton Picker"; and Alston and Ferrie, "Paternalism." Cogan in "Decline" sets forth a view consistent with the displacement hypothesis concerning the rise in postwar black teenage unemployment. Margo and Finegan in "Decline," though, show that Cogan overestimated the role of mechanization with respect to the decline in black teenage labor-force participation. Focusing on migration rather than the harvest labor market, Heinicke in "African-American Migration" attributes, at most, a quarter of the migration during the 1950 s to the picker alone.

${ }^{6}$ Peterson and Kislev, "Cotton Harvester," p. 214, analyzed the hand-harvest labor market for all states that predominantly used mechanical cotton pickers, excluding Texas and Oklahoma where growers used stripping machines. Recently Donald Holley, replicating Peterson and Kislev's empirical approach with some modifications, attributed 60 percent of the decline in cotton harvest employment
} 
elsewhere, made more recently by Donald Holley, implies rising harvest wages when, in fact, picking pay declined over the period in question. ${ }^{7}$

Our objective in this article is to estimate the causes of the demise of the cotton-harvest work force in the 12 major cotton-producing states from 1949 to $1964 .{ }^{8}$ We use much-improved data and we estimate the effect of each of the principal factors involved, instead of making a head-to-head comparison of the effect of industrial wages versus machine displacement. ${ }^{9}$ Our econometric results indicate declines in both cotton-picking labor supply and demand, but that demand shifts dominated. We find that mechanization and government acreage reduction programs formed the main impetus to rid the cotton fields of hand labor for good - that is, collapsing labor demand drove workers from the cotton belt that stretched from California to the Carolinas. Nonagricultural wages, according to our estimates, drew farm workers away, although to a much smaller extent than reported by Peterson and Kislev or Holley.

Establishing the causes of the decline of cotton hand harvest labor matters because the federal government heavily subsidized and coordinated the mechanization of cotton production, but failed to absorb the adjustment costs of those harmed by the results. ${ }^{10}$ In contrasting their conclusions with the

to higher industrial pay and 40 percent to technological labor displacement. See Second Great Emancipation, p. 173

${ }^{7}$ We thank the editor for this point. Perhaps such seemingly contradictory evidence could be reconciled by recognizing the confusion that arises from Peterson and Kislev's and Holley's narrow framework of analysis - a head-to-head comparison of industrial wage "pull" versus machine displacement "push"which ignores the effects of other important factors, namely cotton prices and government programs. Thus, conceivably, the effect of manufacturing earnings exceeded that of cheaper harvest machines and yet harvest wages could have fallen if net demand-side shifts outweighed decreases in supply.

${ }^{8}$ One problem that has plagued earlier studies is the synonymous treatment of decline of handharvested cotton and migration. The reader should be alert to an asymmetry-once workers left for better opportunities, they rarely returned, at least for decades, as they took up permanent urban residence. Yet many of those displaced by machines may not have migrated but may have resided in the locality, wandered into small towns, or migrated later on. Thus, pockets of poverty that persisted in the South could have resulted in part from displaced nonmigrants, an outcome consistent with Margo's findings in Race that selective migration included those with relatively high human capital.

${ }^{9}$ The 12 major cotton-growing states where growers predominantly used mechanical pickers are Alabama, Arizona, Arkansas, California, Georgia, Louisiana, Mississippi, Missouri, New Mexico, North Carolina, South Carolina, and Tennessee.

${ }^{10}$ Government subsidies and coordination to mechanize cotton production resulted from an attempt to maintain the international competitiveness of American cotton. Many farm experts had long advocated shifting labor out of cotton, essentially arguing for a reallocation of labor resources to increase long-run social welfare both of those who remain in agriculture and for the nation as a whole (see Fite, Cotton Fields). Petitions for retraining or relocation assistance for displaced farm workers failed to be enacted (see Committee for Economic Development, “Adaptive Program," p. 30). Unlike farm laborers, for 30 years the federal government has aided, through the Trade Adjustment Assistance program, workers who experienced trade-related job loss (see Kletzer, Job Loss). Martin and Havlicek in "Some Welfare Implications" estimated substantial benefits to consumers and producers of cotton harvest mechanization but their partial equilibrium framework did not permit quantification of the direct impact on the labor market. Maddox, "Private and Social Costs," identifies three broad categories of costs: those that fall on migrants themselves, the communities from which they move, and the communities to which they move. 
prevailing "tractored-off-the-land" view, Peterson and Kislev note that the "issue addressed is of more than academic interest. If labor has in fact been pushed out of agriculture, then the research establishment and farm machinery companies share responsibility for the social costs of the largescale migration of farm people." 11 Reversing the welfare implications of this episode of technological change, our empirical results provide the first comprehensive explanation for the demise of the hand harvest cotton labor force which has factored importantly in post-World War II United States economic history.

\section{CONTEMPORARY VIEWS OF THE DECLINE IN HAND HARVESTING OF COTTON}

The most commonly held view of the demise of hand-harvested cotton, that farm workers were "tractored-off-the-land," reflects the images that emerged from Dorothea Lange's farm-life photographs, John Steinbeck's novel The Grapes of Wrath, and John Ford's film depiction of it. Historian Pete Daniel called the mechanical picker the "central engine of transformation" and referred to migrants as "refugees from mechanization," a view shared, for example, by contemporary journalists Nicholas Lemann and Anthony Walton. ${ }^{12}$ A Humphreys County, Mississippi tenant farmer explained the locus of change as follows:

There used to be a whole lot more people on the plantations than there are now. The machines started long back in ' $50 .$. . Then every year they begin to get more and more, more and more, and that begin to cut people down out of pickin', you know. In other words, before that they were pickin' all the crop. Then after machines got in, they started pickin' ends, see. And so now, the biggest of em not pickin' none. ${ }^{13}$

Anecdotal evidence contrastingly also supports the "labor vacuum" explanation, the argument that the wholesale loss of labor triggered farmers' adoption of mechanical cotton pickers, not the reverse. ${ }^{14}$ In 1950, for example, 75 to 100 growers in South Carolina bought picking machines in

\footnotetext{
${ }^{11}$ Kislev and Peterson, "Cotton Harvester," p. 200.

${ }^{12}$ Daniel, Breaking the Land, pp. 245, 249, respectively; Lemann, Promised Land; Walton, "Technology," pp. 14-18. Also, see Kirby, Rural World; Cobb, Most Southern Place; Fusfeld and Bates, Political Economy; Dillingham and Sly, "Mechanical Cotton Picker," and Alston and Ferrie, "Paternalism" and Southern Paternalism.

${ }^{13}$ Quoted in Dunbar, Our Land, p. 8. David Halberstam, in Fifties, recounts how a University of North Carolina graduate inherited the family plantation, purchased his first mechanical cotton harvester in 1948, the year International Harvester began production, and then "watched the migration taking place as people no longer able to make an acceptable living opted to go north, often in the middle of the night without even a farewell." Ironically, the farmer in question, who cared about and enjoyed reading history, "had been part of so profound a social movement and had never even been aware of it" (pp. 452-53).

${ }^{14}$ See, for example, Street, “'Labor Vacuum.””
} 
case of a labor shortage but continued having the crop picked by hand. ${ }^{15}$ Cotton experts writing in 1954 about the Mississippi delta area commented that planter after planter asserted that "Not one family, not one person has been displaced by machines on this plantation." ${ }^{\prime 6}$ Referring to the Mississippi delta states generally, a 1962 U.S. Department of Labor report concluded that "mechanization has been stimulated by a shortage of seasonal workers at the peak of the harvest period." ${ }^{17}$ In 1977, reflecting back upon the causes of this technological change, Jere Nash Sr., founder of the Delta Implement Company, stated that "the cotton picker did not displace workers, but did replace them."18

\section{THE POSTWAR COTTON ECONOMY}

Despite the prosperity of commodity markets brought on by World War II, at war's end unrelieved pessimism pervaded the U.S. cotton sector. A series of hearings of cotton-industry interests, convened by the Special Subcommittee on Cotton, enumerated the short-term and long-run reasons for a bleak outlook, analyses of which were published in 1947 as the Study of Agricultural and Economic Problems of the Cotton Belt. ${ }^{19}$ Two grave threats clouded growers' future: the prospect of falling and unprofitable cotton prices and insufficient labor to plant, chop, and bring in the crop. Low prices seemed likely due to huge surpluses of cotton here and abroad, increasing amounts of inexpensive foreign production, and competition from synthetic fibers. ${ }^{20}$ Cotton prices did trend downwards from World War II through the 1960 s, prompting many farmers to reconsider the opportunity cost of devoting their land and labor to cotton. Such long-run adverse commodity price movements motivated precisely the kind of diversified southern agriculture farm experts had long advocated. ${ }^{21}$

Given the expectation of falling cotton prices, the prospect of a mass exodus of labor heightened growers' worst fears of a shortage of workers or excessively high wages. Mobilization for World War II, including the defense and related industries and the military itself, wrenched the cotton labor market from surplus to shortage. In the postwar era, rising nonagricultural

\footnotetext{
${ }^{15}$ Street, New Revolution, p. 393.

${ }^{16}$ Pederson and Raper, Cotton Plantation, p. 8.

${ }^{17}$ U.S. Department of Labor, "Cotton,” p. 6.

${ }^{18}$ Holley, Second Great Emancipation, p. 144.

${ }^{19}$ The Special Committee on Cotton of the House Committee on Agriculture, headed by Rep. Stephen Pace of Georgia, met in December 1944 and May 1945 and sponsored nine projects investigating the problems facing cotton, which were published in July and October 1947 as the Study of Agricultural and Economic Problems of the Cotton Belt, U.S. House Committee on Agriculture.

${ }^{20}$ See Street, New Revolution, pp. 77-85, for the contemporary postwar concerns and projection. For example, the largest single end-use product for cotton prior to the war (tire cord and fabric) quickly converted to rayon (ibid., p. 80).

${ }^{21}$ Fite, Cotton Fields.
} 
pay induced rural-urban migration to jobs in burgeoning manufacturing, construction, and retail sectors that offered more stable, secure employment than did cotton. The system of harsh racial segregation dictated by "Jim Crow" laws and customs provided an additional impetus for black migration from the South. In spite of growers' fears of labor scarcity, piece-rate picking wages declined by 31 percent from 1949 to 1964, twice as rapidly as did cotton prices (16 percent) in real terms. ${ }^{22}$

Another key element in the labor-demand picture was the role of federal government acreage reduction programs. The government limited the amount of land planted to cotton by mandating successively smaller acreage "allotments" for individual growers, adherence to which enabled producers to sell their crops at government-supported above-market prices. ${ }^{23}$ Acreage allotments, suspended during the war years, were in effect in 1950 and from 1953 to 1964 . In addition, the Soil Bank program paid growers to plant soil conserving grasses instead of "soil depleting" crops such as cotton. ${ }^{24}$ Payments to growers reflected potential earnings from planting a crop on acreage of average quality, but without the uncertainty and effort that planting, cultivating, and harvesting a crop entailed. ${ }^{25}$ Although only in effect in four years, 1956-1958 and 1964, generous incentives reduced cotton acreage and, thus, labor demand. In 1958, the year the Soil Bank exerted its greatest effect on cotton acreage, farmers nationwide diverted 4.9 million acres from cotton, equal to 29 percent of the land planted to cotton in $1956 .{ }^{26}$ Regional grower responsiveness to this incentive varied sharply: growers in Alabama, South Carolina, and Georgia, for example, planted acreages equal to 52, 48, and 43 percent of their allotted acreages compared to 96 and 92 percent for those in Arizona and California. ${ }^{27}$ With the suspension of the Soil Bank acreage reserves in 1959, cotton planting rebounded in the Delta, although never completely in the southeast where more marginal land existed. ${ }^{28}$ Despite the Soil Bank's temporary nature, a severe reduction in labor demand may have sufficiently diminished laborers' incomes during those years to induce permanent out-migration from the region.

\footnotetext{
${ }^{22}$ USDA, Statistics on Cotton.

${ }^{23}$ Acreage allotments, based on historical production, were linked to a national "marketing quota" to limit the supply of cotton and other staple farm products (Arkansas Agricultural Experiment Station, Chronology).

${ }^{24}$ This program had precedents in the 1935 "Soil Conservation Act" and the 1936 "Soil Conservation and Domestic Allotment Act" (see Arkansas Agricultural Experiment Station, Chronology, pp. 7-9, 19-20). Under the "acreage reserve" part of the program (the conservation reserve clause had little effect on cotton planting), farmers received an amount close to the net returns per acre to withdraw land from cotton below that of allotted acreage.

${ }^{25}$ Thus, land of below average quality would have generated lower returns than accepting the Soil Bank payment (Heinicke, "Federal Soil Bank").

${ }^{26}$ Cochrane and Ryan, American Farm Policy, p. 225.

${ }^{27}$ See USDA, Statistics on Cotton for planted acreage data (tables 47-79, pp. 64-79) and acreage allotment data (table 46, pp. 61-62)."

${ }^{28}$ Heinicke, "Federal Soil Bank."
} 
Finally, a rapid, 81-percent rise in cotton yields occurred from 1949 to 1964, an annual average of 15.5 pounds of lint. ${ }^{29}$ Raymond Christinsen and Ronald Aines attributed over half the yield gains of the 1950s to the heavy use of more powerful fertilizers, in part motivated by an effort to boost lint output per acre to offset the effects of the acreage reduction programs. ${ }^{30}$

\section{COTTON HARVEST MECHANIZATION}

In the century before World War II inventors devoted great effort, time, and money to develop a mechanical alternative to the arduous task of gathering cotton by hand. ${ }^{31}$ Compared to wheat and corn, the cotton harvest proved quite resistant to mechanization. Although John and Mack Rust offered the most promising device through the 1930s based on early success in field trials, the Rust machine failed to achieve commercial success due to the lack of a few key technical features and the consequences of the Great Depression. ${ }^{32}$ Following World War II, a breakthrough occurred when a onerow picker was mounted onto the rear of a Farmall tricycle tractor so that it could be driven down the rows in reverse. Finally, in April 1948 International Harvester began commercial production of spindle picking machines, which simulated hand harvesting by rotating moistened, barbed spindles through the plant and pulling the cotton bolls from their bur. ${ }^{33}$ Soon a number of manufacturers offered farmers a variety of machine models suited to their vast array of field conditions, sizes of operation, and budgets. ${ }^{34}$

This study evaluates the 12 major cotton-producing states in which growers predominantly used "spindle" pickers. We exclude Texas and Oklahoma where growers widely used the alternative, cotton-stripping, device. ${ }^{35}$ Production organization and labor markets varied by region, with the plantation and tenancy only important in the South. ${ }^{36}$ Instead of annual contract labor,

\footnotetext{
${ }^{29}$ These are three-year averages of U.S. harvested yield centered of the listed years from USDA, Statistics on Cotton, p. 63.

${ }^{30}$ Christinsen and Aines, Economic Effects, p. 23

${ }^{31}$ For a description of the principal innovators and innovations, see Street, New Revolution, Ch. 6; and Holley, Second Great Emancipation, Ch. 6.

${ }^{32}$ In 1946 machines gathered virtually no cotton compared to 90 percent of the acreage of small grains, United States Bureau of the Census, Historical Statistics.

${ }^{33}$ In 1943 the War Production Board rejected International Harvester's application to build a mechanical picker factory (see Holley, Second Great Emancipation, p. 104).

${ }^{34}$ Meier, "Economic Analysis"; and Holley, Second Great Emancipation. Deere and Company began commercial production in 1950 (of the first self-propelled two row machine as well as a smaller devise to be mounted on a tractor), Allis-Chalmers in 1949, and Ben Pearson in 1949 (Holley, pp. 104-11).

${ }^{35}$ In contrast to the spindle machine that "picked" the cotton boll from the bur, the nonselective mechanical stripping machine stripped all vegetation from the plant (see Grove, "Economics"). For the 1960-1964 period, Oklahoma farmers gathered 62.4 percent of the their cotton crop by mechanical stripper, Texans 55.8 percent, New Mexicans 12 percent, and Arkansans, the state with the next largest percentage, 1.3 percent (USDA, "Charges for Ginning Cotton," 1961-1965).

${ }^{36}$ See Heinicke, "Southern Tenancy," for the period before the mechanical picker.
} 


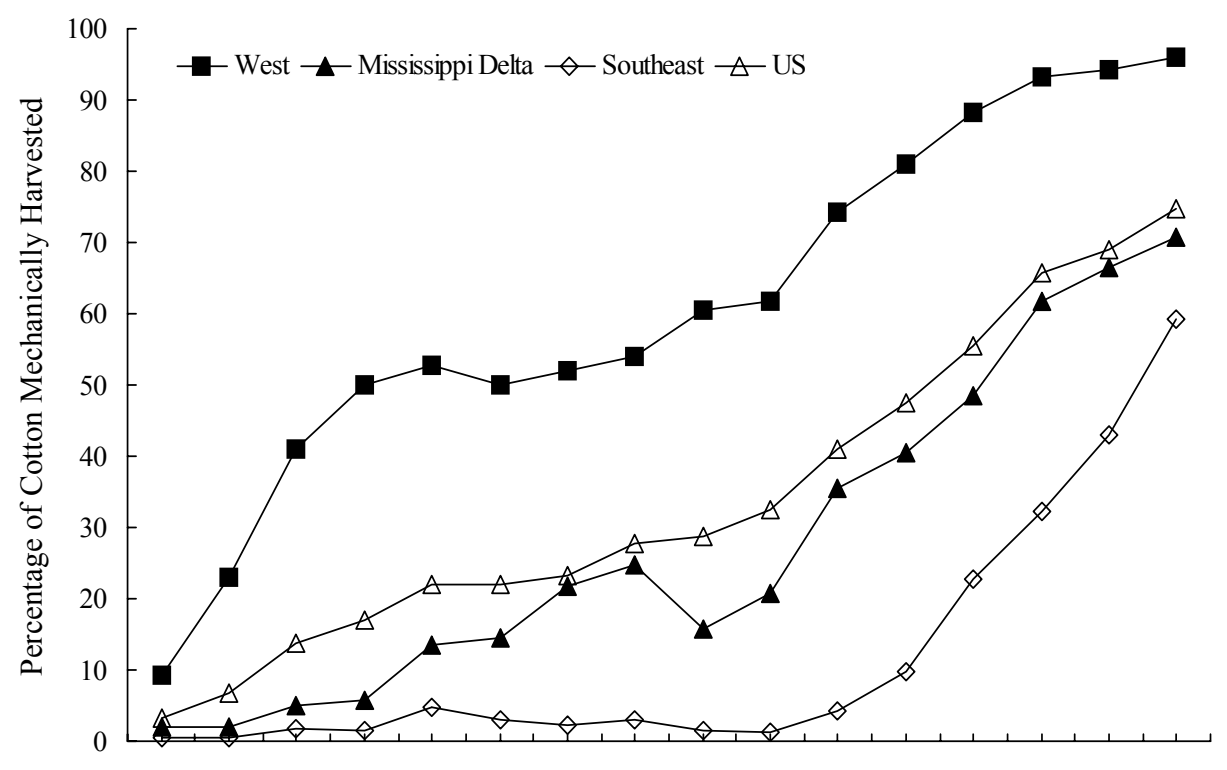

1949195019511952195319541955195619571958195919601961196219631964

FIGURE 1

PERCENTAGE OF COTTON HARVESTED BY SPINDLE PICKERS BY REGION AND FOR THE UNITED STATES, 1949-1964

Note: These are weighted averages of cotton production of mechanically picked lint, which exclude production in Texas and Oklahoma where growers used mechanical strippers. Regions: West: Arizona, California, and New Mexico; Mississippi Delta: Arkansas, Louisiana, Mississippi, and Missouri; and Southeast: Alabama, Georgia, North Carolina, South Carolina, and Tennessee.

Sources: Percentage of cotton crop harvested by machine per state: U.S. Department of Agriculture, Statistics on Cotton, p. 218. Bales of cotton harvested per state: ibid., pp. 64-77.

i.e., tenants and sharecroppers, western growers hired the available local labor and then satisfied the remainder of their harvest labor requirements with domestic and foreign migrants. ${ }^{37}$ Scientific agriculture flourished in the west: large, flat fields suited machine use, the arid climate was pest-free and allowed (irrigated) water to be delivered optimally, and chemicals could stimulate production and simulate a killing frost to aid the harvest. ${ }^{38}$

Diffusion of the mechanical cotton picker across the pan-continental Cotton Belt occurred with surprising speed and in a distinctive west-to-east pattern as shown in Figure 1. Western producers rapidly adopted mechanical harvesters as soon as the new technology became commercially available, whereas Mississippi delta planters steadily increased mechanization of the harvest throughout the 1949-1964 period. Southeastern growers, by contrast,

\footnotetext{
${ }^{37}$ Grove, "Economics."

${ }^{38}$ See Musoke and Olmstead, "Rise"; and Grove, "Economics." Broadly speaking, the cotton belt can be divided into the four regions: the southeast (Alabama, Georgia, North Carolina, South Carolina, and Tennessee), the Mississippi delta (Arkansas, Louisiana, Mississippi, and Missouri), the southwest (Oklahoma and Texas), and the west (Arizona, California, and New Mexico).
} 
almost exclusively gathered the crop by hand through the 1950s but thereafter rapidly mechanized the harvest. Table 1 provides the expected real machine-harvest and hand-harvest costs per pound of lint that coincide with the west-to-east pattern of picker diffusion of Figure $1 .{ }^{39}$

Although differences in machine-to-hand cost ratios explain much of the uneven pace of mechanization across the Cotton Belt, cheaper average mechanical than manual harvest methods did not lead to dramatic rates of mechanization. The transition to machine harvesting varied considerably, for example, even among the largest plantation operations in the Mississippi delta, the production units presumably with the least capital constraints and the most information about best practice techniques. While the Hopson Plantation in Clarksdale, Mississippi, picked all cotton with experimental International Harvester machines beginning in 1944, the Lee Wilson and Co., a 50,000 acre plantation in Arkansas, only began mechanical harvesting in the late $1950 \mathrm{~s} .{ }^{40}$ Paternalistic relations help explain delayed technological change because some plantation operators "do not displace these individuals with machines; instead, they are replaced by machines through a process of attrition." 41 Most importantly, though, the harvest was but one of three phases of the annual cycle of cotton production with many complicated relationships. ${ }^{42}$ Even if tractors could prepare, plant and cultivate the land and picking machines could gather the crop, until the late 1950s the crop was best thinned and weeded by hand. ${ }^{43}$ Ultimately, tractors would do the fieldwork and apply chemicals that weeded, fertilized, protected against insects, and defoliated the vegetation in the fields. ${ }^{44}$ Although some southerners watched this technological onslaught from behind their mules, most did so from the North.

The post-World War II Washington, D.C. meetings about cotton's future led to one tangible outcome: passage of the Research and Marketing Act of 1946 that doubled agricultural research funds and helped develop the chemomechanical system of cotton production that ultimately eliminated farmers'

\footnotetext{
${ }^{39}$ Figure 1 indicates that western growers harvested a smaller portion of the crop in 1954 and 1955 than in 1953. Cotton plantings rapidly expanded in the West when acreage allotments were suspended from 1951-1953 aided by an equally rapid adoption of picking machines. With the reimposition of allotments growers there reduced the amount of cotton gathered by machine more than that by hand. The fall in mechanization in 1957 and 1958 in the Mississippi Delta resulted from unusually wet weather during the harvests of 1957 and 1958 (see Holley, Second Great Emancipation, p. 154).

${ }^{40}$ Holley, Second Great Emancipation, pp. 139, 243.

${ }^{41}$ LeRoy and Crowe, "Labor," p. 19.

${ }^{42}$ Cotton production entailed three phases: land preparation and planting, weeding and thinning, and harvesting.

${ }^{43}$ Growers in the humid south faced a weeding labor constraint but not those in the semi-arid west. For an explanation of the southern tenant plantation as a response to adverse weather conditions, see Grove, "Economics."

${ }^{44}$ While planting, growers applied pre-emergent herbicides, which, under the right conditions, could retard weeds for a month, after which post-emergent chemicals killed weeds.
} 
TABLE 1

EXPECTED REAL COST OF MACHINE-HARVESTED AND

HAND-PICKED COTTON BY REGION, 1949-1964 (cents per pound of lint)

\begin{tabular}{|c|c|c|c|c|c|c|}
\hline & \multicolumn{2}{|c|}{ West } & \multicolumn{2}{|c|}{ Mississippi Delta } & \multicolumn{2}{|c|}{ Southeast } \\
\hline & $\begin{array}{c}\text { Machine } \\
\text { Cost }\end{array}$ & $\begin{array}{l}\text { Hand } \\
\text { Cost }\end{array}$ & $\begin{array}{c}\text { Machine } \\
\text { Cost }\end{array}$ & $\begin{array}{l}\text { Hand } \\
\text { Cost }\end{array}$ & $\begin{array}{c}\text { Machine } \\
\text { Cost }\end{array}$ & $\begin{array}{l}\text { Hand } \\
\text { Cost }\end{array}$ \\
\hline 1949 & 6.9 & 13.1 & 9.4 & 11.8 & 11.1 & 10.7 \\
\hline 1950 & 7.5 & 11.5 & 10.5 & 10.8 & 12.9 & 9.9 \\
\hline 1951 & 7.3 & 16.1 & 11.1 & 13.6 & 14.5 & 12.1 \\
\hline 1952 & 6.6 & 15.2 & 9.2 & 12.5 & 11.2 & 11.3 \\
\hline 1953 & 5.8 & 13.4 & 8.9 & 11.1 & 11.2 & 10.7 \\
\hline 1954 & 5.8 & 13.1 & 8.6 & 11.1 & 10.7 & 10.3 \\
\hline 1955 & 5.6 & 13.5 & 8.0 & 11.0 & 10.0 & 10.5 \\
\hline 1956 & 5.6 & 13.0 & 8.0 & 10.7 & 10.8 & 10.0 \\
\hline 1967 & 5.6 & 12.1 & 7.8 & 9.5 & 10.6 & 9.2 \\
\hline 1958 & 5.4 & 12.0 & 7.9 & 8.6 & 10.1 & 8.4 \\
\hline 1959 & 5.0 & 12.1 & 7.5 & 9.8 & 9.2 & 9.7 \\
\hline 1960 & 4.4 & 11.0 & 7.0 & 9.0 & 8.9 & 8.3 \\
\hline 1961 & 3.7 & 10.1 & 6.3 & 8.1 & 8.1 & 8.4 \\
\hline 1962 & 3.5 & 11.1 & 5.8 & 8.7 & 7.7 & 9.0 \\
\hline 1963 & 3.4 & 10.5 & 5.7 & 8.0 & 7.9 & 8.7 \\
\hline 1964 & 3.3 & 10.5 & 5.6 & 7.7 & 8.0 & 8.5 \\
\hline
\end{tabular}

Notes: Real values deflated by U.S. CPI $(1960=100)$. Regions: West: Arizona, California, and New Mexico; Mississippi Delta: Arkansas, Louisiana, Mississippi, and Missouri; and Southeast: Alabama, Georgia, North Carolina, South Carolina, and Tennessee.

Source: See Grove, "Economics of Cotton."

demand for field labor. ${ }^{45}$ The fact that early adopters had figured out how to mechanize all aspects of production and had demonstrated its success helps explain why southeastern growers at the end of our period of analysis so rapidly embraced machine harvesting compared to those in other regions when they faced similar relative harvest cost ratios.

\section{COTTON HARVEST COSTS}

To date, estimates of the causes of the demise of cotton hand-harvest labor have taken place in something of an empirical vacuum without good measures of farmers' expected costs of harvesting their cotton crop by hand and by machine. Frank Meier estimated machine harvest costs for the spindle-

\footnotetext{
${ }^{45}$ The Cotton Mechanization Project sought to modify every aspect of cotton plant growth and the production process to conform to the limitations of the harvesting machine, especially ginning equipment because machine-harvested cotton contained more organic and inorganic debris and more moisture than hand-gathered cotton. The USDA state agricultural R\&D system and extension network, the largest in the world, relied upon biologists, geneticists, chemists, entomologists, mechanical engineers, and many other specialized fields. To share results, compare work, coordinate research agendas, and plan for the future, beginning in 1947 an annual "Belt-wide Cotton Mechanization Conference" assembled farmers and public- and private-sector researchers and administrators.
} 
picker states from 1949 to 1964 in his unpublished dissertation entitled $A n$ Economic Analysis of the Mechanical Cotton Picker. ${ }^{46}$ Machine harvest cost calculations require: data on fixed and variable costs, such as purchase prices, depreciation schedules, interest rates, storage costs, insurance, taxes, tractor costs, repairs, lubricants, fuel, and labor; estimates of the hours of potential use by state during a typical harvest season; estimates of field waste relative to hand picking; and estimates of grade loss relative to hand picking. ${ }^{47}$ Although Peterson and Kislev used Meier's data in their working paper and Holley does in his book, Peterson and Kislev's published article in this JOURNAL used their estimates of custom machine harvest rates. (More on this will follow.)

Unfortunately, to date hand harvest costs have been measured only by using the USDA "piece rate wages," growers' payment to fieldhands for each 100 pounds of seed cotton harvested. ${ }^{48}$ These cash wages, however, poorly capture growers' total hand harvest costs. An important contribution of this article is to advance an improved measure of this variable. First, growers care about unit costs per pound of cotton lint but paid workers per 100 pounds of unprocessed "seed-cotton." The raw cotton contained varying amounts of organic and inorganic matter (removed at the cotton gin) that differed over time and by location. For example, in 1960 in Arizona it took 1,597 pounds of hand-picked seed cotton to obtain a bale of lint but only 1,334 pounds in Mississippi. Secondly, piece rates ignore the employers' nonwage expenses of organizing the harvest, recruiting workers, and providing in-kind compensation such as food, housing, and transportation. Nonwage costs varied by region and according to whether the harvest workers resided in close proximity to the farm, in a nearby village or city, outside the area, or outside the United States. ${ }^{49}$ Growers generally incurred only wage expenses for resident workers who lived within walking distance, whereas town or day-haul labor had to be transported and recruited daily. In the Delta and Southeast, migrant laborers living away from home tended to receive more in-kind benefits, especially in the form of housing and meals, than did local workers. Finally, growers employing foreign contract workers through the U.S. Department of Labor's Mexican Farm Labor Program were required to pay the greatest expenses due to the federally mandated terms of compensation and living and working conditions. ${ }^{50}$

\footnotetext{
${ }^{46}$ Meier's data have since been corrected by Warren Whatley, "New Estimates," to add the cost of the machine operator's "helper" and by Grove, "Economics," to include additional ginning costs associated with machine harvesting.

${ }^{47}$ Field losses refer to unharvested lint that remained in the field, whereas grade losses indicate a reduction in quality and, hence, value (as judged by whiteness and staple length).

${ }^{48}$ Whatley, "New Estimates." Grove, "Economics," makes this point regarding the empirical work of Peterson and Kislev, "Cotton Harvester," and the same applies to Holley, Second Great Emancipation.

${ }^{49}$ Grove, "Economics."

${ }^{50}$ Grove, "Economics" and "Mexican Farm Labor." Especially during the early 1950s the Department of Labor exerted little oversight and braceros failed to receive the mandated compensation package.
} 
Grove in "Economics of Cotton" estimated a time series of hand harvest costs to match the Meier machine cost data by converting piece-rate wages to cash wages per pound of lint and by estimating nonwage costs for resident laborers, day-haul workers, domestic migrants, and foreign contract workers. Determination of nonwage expenses required estimating the annual cotton harvest labor shares of each type of labor by state from 1949 to 1964 because harvest organization and recruitment expenses and in-kind compensation varied for each. Annual state hand harvesting costs are obtained by combining state wage and nonwage labor expenses, weighted according to the types of labor employed. ${ }^{51}$

\section{THE COTTON HAND-HARVEST LABOR MARKET: MODEL AND DATA}

The objective of this article is to determine the extent to which factors either lured laborers away from the cotton belt (shifted supply leftward) or drove them from it (shifted demand leftward). Falling cotton-harvest wages during the post-World War II period suggest that demand shifts must have dominated those affecting supply. If that is so, we do not know whether harvest labor demand shifted due to mechanization, cotton prices, government programs, or some combination thereof. Also, an inspection of wage data fails to reveal the contribution of nonagricultural wages in drawing workers out of the cotton harvest, which could be at work despite the fact that falling harvest wages signify decreases in demand outweigh those in supply. In order to quantify these effects, we estimate the shifts in the supply of and demand for cotton harvest labor for 12 states from 1949 to 1964 . In our model the demand for hand harvest labor $(Q d)$ is a function of last season's hand-harvest output $\left(Q_{t-1}\right)$, the cotton harvest wage $(W)$, machine prices (MCOST), the (lagged) price of cotton (PCT), grower overhead expenses $(O V E R H)$, the two government acreage restriction programs (ALLOT and $S O I L)$, cotton yields $(Y)$, and state dummy variables $(S D)$.

$$
\begin{aligned}
Q d_{t i}= & \alpha_{0}+\alpha_{-1} Q_{t-1, i}+\alpha_{1} W_{t i}+\alpha_{2} \operatorname{MCOST}_{t i}+\alpha_{3} P C T_{t-1, i}+\alpha_{4} O_{V E R H_{t i}}+ \\
& \alpha_{5} \operatorname{ALLOT}_{t i}+\alpha_{6} \operatorname{SOIL}_{t i}+\alpha_{7} Y_{t i}+\alpha_{8 i} S D_{i}+\mathcal{\varepsilon}_{d t i}
\end{aligned}
$$

As the ideal measure of harvest labor (the dependent variable), labor per unit time period or the number of hours and days required to harvest a given amount of cotton is not known, we used the total quantity of cotton harvested by hand. Lagged output accounts for the partial adjustment of hand-harvested output. ${ }^{52}$ Our "wage" variable, the total compensation of labor employed in

\footnotetext{
${ }^{51}$ Details of these series can be found in Grove, "Economics," or in a more extensive working paper (Grove and Heinicke, "Better Opportunities") available upon request.

${ }^{52}$ Nerlove, "Dynamics." Dickey Fuller tests reject the hypothesis of a unit root at the 1-percent level with or without deterministic trend; for a discussion of such tests in a panel context, see Im, Pesaran, and Shin, "Test."
} 
the cotton harvest $(W)$, is the cash wage plus the value of in-kind benefits. The machine harvest costs (MCOST) are the estimated expenses per pound of cotton lint ${ }^{53}$ Because growers make decisions on the basis of the expected output price, we include the price of cotton lagged one year $(P C T)$. In part the demise of the Old South included the demise of cotton as the most important commodity because production shifted from the lower yield southeastern region (the Carolinas, Georgia, Alabama, and Tennessee) to the high-yielding areas in California, Arizona, New Mexico, and West Texas. The price of cotton reflected such changes as more efficient producers expanded their share of cotton. In addition, cotton prices suffered due to competition from synthetic fibers and foreign producers. Because landowners incurred noncash costs associated with organizing the harvest, recruiting a work force, and providing in-kind compensation, we include the overhead costs of employing hand harvesters $(O V E R H)$ as a separate variable. ${ }^{54}$

Finally, government acreage reduction programs caused a decline in the demand for harvest labor. ${ }^{55}$ In 1950 and from 1953 to 1964, federal acreage allotments $(A L L O T)$ imposed acreage ceilings on growers, reducing labor demand.$^{56}$ In 1956-1958 and 1964 the USDA's Soil Bank program (SOIL) paid growers to plant grass to conserve the soil, further reducing cotton acreage. We measure the impact of allotments with the actual allotted acreage for each state, but are only able to account for the effect of the Soil Bank program with a dummy variable. ${ }^{57}$ Our demand equation includes yield $(Y)$ because cotton grower demand for labor, for a given planted acreage, varied along with output per acre. State dummy variables $(S D)$ are included to control for unmeasured variations across states.

We model the cotton harvest labor supply function as follows

$$
\begin{aligned}
Q s_{t i}= & \beta_{0}+\beta_{-1} Q_{t-1, \mathrm{i}}+\beta_{1} W_{t i}+\beta_{2} W N O N_{t i}+\beta_{3} Y_{t i}+\beta_{4} P R E H W_{t i}+ \\
& \beta_{5} A C R E S_{t i}+\beta_{6 i} S D_{i}+\mathcal{E}_{S t i}
\end{aligned}
$$

The lagged hand-harvested output $\left(Q_{t-1}\right)$, harvest labor compensation $(W)$ and state dummies $(S D)$ are the same as in the demand function. To reflect opportunities outside of agriculture, we constructed a series relevant to those working in the harvest to reflect the level of wages in both the origin and destination state of interregional migrants $(W N O N)$, because African-Ameri-

\footnotetext{
${ }^{53}$ See Grove, "Economics."

${ }^{54}$ Ibid.

${ }^{55}$ For studies of the role of government programs in labor displacement with respect to earlier periods, see Fligstein, Going North; and Whatley, "Labor."

${ }^{56}$ Heinicke, "Federal Soil Bank."

${ }^{57}$ We know of no state-level data for acreage diverted under the Soil Bank program. The Soil Bank dummy variable we use may measure other shocks, a matter discussed in the results section. Three observations were missing: the 1950 values for the western states. Given the allotments percentages of planted acreage for 1954 in these states (100 percent for Arizona, 95 percent for California and New Mexico), these three values were set to equal planted acreage in 1950 .
} 
cans, and to a lesser extent whites, migrated to northern urban centers. ${ }^{58}$ To measure the fact that northern wages exceeded southern pay during this period, we computed the average of manufacturing wage rates between the cotton producing state in question and the primary destination state of migrants. ${ }^{59}$ Although an improvement over using only the national average manufacturing wage rate for each state, our nonfarm wage series does not adjust for the fact that the potential migrant must have discounted any expected wage rate in a destination region by the costs of migration broadly interpreted or the likelihood of experiencing unemployment. ${ }^{60}$

Because labor compensation depends upon the amounts of cotton picked, cotton yield $(Y)$ is included in the supply equation. ${ }^{61}$ Higher yields meant that a worker could expect more harvest-time employment and greater seasonal income, inducing a larger supply of labor for a given rate of compensation. Less weeding, chopping, and other preharvest tasks due to reduced cotton acreage would have lowered preharvest income and, hence, tended to reduce the stock of local laborers available for the harvest season. ${ }^{62}$ Measuring preharvest income accurately is fraught with difficulties, but its omission could potentially bias the results if changes in labor supply were highly correlated with preharvest income, and if such income were related to included variables, a likely occurrence. To measure the variation of preharvest compensation and the amount of before harvest employment, we add the state average wage rate in agriculture $(P R E H W)$ and cotton acreage planted $(A C R E S)$ to the supply function. ${ }^{63}$ Because landowners sold and

\footnotetext{
${ }^{58}$ See Johnson and Campbell, Black Migration; Gill, Economics; and Lemann, Promised Land.

${ }^{59}$ The "primary" destination state was that to which the previous decade's migration from the state had been the greatest (calculated from Eldridge and Kuznets, Population). We adjusted the destinationstate wage by a regional cost-of-living index. To reflect the fact that cotton harvest workers could not generally expect the average wage in manufacturing, we multiplied both the in-state and destinationstate wage by the ratio of the overall average to the average earnings of laborers and operatives in manufacturing from the relevant Census of Population, linearly interpolated for each year (for cost of living indices, see Williamson and Lindert, American Inequality). Without adjustments for the widening skilled-unskilled wage gap that occurred in the 1950s, Peterson and Kislev, "Cotton Picker"; and Holley, Second Great Emancipation, may have overestimated the effect of nonagricultural wages (see Maloney, "Wage Compression").

${ }^{60}$ For a complete discussion, see Gill, "Economics"; and Carrington et al., "Migration." The unemployment rate serves the function of discounting the wage rate, but no state-level annual unemployment data are available for our time period (Blanchard and Katz, "Regional Evolutions," p. 11).

${ }^{61}$ The previous empirical studies by Peterson and Kislev, "Cotton Picker"; and Holley, Second Great Emancipation, included yield only in the supply function. We estimate both versions for comparative purposes (see results section).

${ }^{62}$ Whatley ("Southern Agrarian Labor Contracts") made a similar argument regarding reduced preharvest income due to mechanized tasks.

${ }^{63}$ The model above, of course, reflects decisions about the endogeneity of variables. Some variables here are obviously predetermined (e.g. the lagged cotton price, planted acreage, and cotton allotments), but others require economic judgement and knowledge. Because events in the harvest season affected wages and quantity employed, these are clearly endogenous. Yields are largely determined before the harvest, due to fertilizer applications, weather, cultivation techniques, insect damage, and other factors that operate during the growing season. We also think wages in the north and outside of agriculture,
} 
TABLE 2

MEANS AND STANDARD DEVIATIONS, $N T=192$

(all money values are expressed in $1960=100$ dollars)

\begin{tabular}{|c|c|c|}
\hline \multicolumn{3}{|l|}{ Panel A } \\
\hline Variable & Mean & $\begin{array}{c}\text { Standard } \\
\text { Deviation }\end{array}$ \\
\hline Hand-harvested cotton, thousand bales & 512.30 & 353.4 \\
\hline Labor compensation, cents per pound of lint & 12.16 & 6.56 \\
\hline Cotton price (cents per pound of lint) & 37.60 & 4.42 \\
\hline Mechanical harvesting costs (cents per pound of lint) & 8.27 & 2.53 \\
\hline Overhead costs of labor (cents per pound of lint) & 0.89 & 0.28 \\
\hline Nonagricultural wage rates (dollars per hour) & 1.68 & 0.26 \\
\hline Cotton yields (pounds per acre) & 509.32 & 227.0 \\
\hline Preharvest agricultural wage (dollars per hour without room or board) & 0.74 & 0.21 \\
\hline Planted cotton acreage (thousands) & 847.36 & 551.25 \\
\hline Cotton allotment (thousands, for years in effect) & 790.2 & 436.8 \\
\hline Soil bank dummy & 0.25 & 0.43 \\
\hline \multicolumn{3}{|l|}{ Panel B } \\
\hline Average Growth of Variables from $\log (x)=a+r t+s d+e$ & $\hat{r}$ & $\operatorname{se}(\hat{r})$ \\
\hline Hand-harvested cotton & -0.094 & 0.006 \\
\hline Labor compensation & -0.026 & 0.001 \\
\hline Cotton price & -0.016 & 0.001 \\
\hline Mechanical harvesting costs & -0.040 & 0.001 \\
\hline Nonagricultural wage rates & 0.019 & 0.0007 \\
\hline Cotton yields & 0.040 & 0.002 \\
\hline Overhead costs of labor & 0.053 & 0.003 \\
\hline Preharvest agricultural wage & 0.012 & 0.0007 \\
\hline Allotment & -0.011 & 0.002 \\
\hline Planted cotton acreage & -0.042 & 0.003 \\
\hline
\end{tabular}

Note: See the text.

purchased in national markets, prices are deflated by the U.S. CPI. For means and growth rates of all variables, see Table 2 . We convert all continuous variables to natural logs in the analysis.

\section{EMPIRICAL RESULTS}

To determine the relative influence of factors upon the demise of handharvested cotton, we estimate both a structural model and a reduced form model of this market. For the structural model, we estimate the supply of and demand for cotton picking labor using two-stage least squares regressions run on the pooled time-series of state level, annual observations for the 12 major spindle-picker states, regarding $Q$ and $W$ as endogenous, and assuming

although influenced over time by movements out of agriculture, adjusted more slowly than wages in the harvest labor market, where they could adjust rapidly to supply and demand in the casual market. This is bolstered by observing the seasonal variation in agricultural wages (see various Farm Labor issues for the years of our time series). 
the market clears each harvest season. ${ }^{64}$ We employed Fair's method in our estimation to address the presence of autocorrelation in the supply equation (Durbin's $h=3.35) .{ }^{65}$ Given the necessity of using lagged values in the first stage of the estimation, (the "lagged-dependent" variable must be lagged two years), the full structural model uses only 156 cross-section-time-series observations out of 192. By contrast, reduced form estimates use the full sample. ${ }^{66}$ The model choice involves a trade-off. Specification of the structural model insures that the full range of supply and demand variables will be included where available. Also, the structural model reduces the multicollinearity that can arise when all of the exogenous variables are included in a single equation. On the other hand, the reduced form serves for more straightforward computations that do not depend on estimates of all the structural parameters, as well as permitting inclusion of the full 192 observations. For these reasons, we present both the reduced form and structural estimates for comparison.

We estimate the structural model both with yield in the demand equation ("Demand 1") and without yield ("Demand 2"). Including yields on the supply side only, implies workers, and not growers, realized the potential for increased output per acre to generate increased seasonal income, a questionable assumption. Nonetheless, we report such a specification of the structural model to facilitate comparison of our results with those of Peterson and Kislev and Holley. The reduced form results show more consistency with the yield-in-demand-and-supply version and make our conclusions less contingent upon this specification decision.

Table 3 presents the parameter estimates for the full supply-demand model and the reduced-form coefficients estimated directly from the data. ${ }^{67}$

\footnotetext{
${ }^{64}$ If this assumption is incorrect, excess supply or demand for labor may result in variations in unemployment. Unfortunately, no state-level time series on unemployment exists for our complete period so we cannot evaluate this possibility. Cotton harvest labor markets appeared well integrated across the cotton belt in agriculture (see Wright, Old South and "Economic Revolution"; and Musoke and Olmstead, "Rise").

${ }^{65}$ See Fair, "Estimation." In the first stage, the endogenous variables are regressed on the predetermined variables and one-year lags. The fitted values are used in the second stage to estimate the autoregressive parameter. In the final stage, the data are transformed and fitted values of the lagged dependent variable is also used to adjust for autocorrelation (see Greene, Econometric Analysis, pp. 748-50). Durbin's $h$ for the demand equation was 0.65 , indicating no autocorrelation.

${ }^{66}$ The reduced form of the model presented in equations 1 and 2 has only two lagged variables, the quantity of cotton $(Q)$ and cotton prices $(P C)$. We obtained data to estimate this equation for 1948 and, thus, for the full 16 years and 12 states. The two-stage-least-squares, Fair method required an additional lag for $X$ (which denotes a generic exogenous variable) and $Q(t-1)$. Therefore, fitted values can only begin in 1950 and in the final stage the use of quasi-first differencing of the fitted values (that is $\hat{\rho} \hat{Q}_{t-2}$ based on $X_{t-1=1949}$ and $X_{t=1950}$ as the first values) means that 1952 is the first year that can be used.

${ }^{67}$ The reduced form actually used in the estimation of the structural model requires additional lags as instruments for the later stage estimates (Greene, Econometric Analysis, p. 749). Our estimates provide similar results as in this article and are available in a working paper (Grove and Heinicke, "Better Opportunities," 2002).
} 
TABLE 3

ESTIMATES

(dependent variable: quantity of hand-harvested cotton)

\begin{tabular}{|c|c|c|c|c|}
\hline \multirow{3}{*}{$\begin{array}{l}\text { Method } \\
\text { Independent Variable }\end{array}$} & \multicolumn{3}{|c|}{ 2SLS Estimates of Structural Equations } & \multirow{3}{*}{$\begin{array}{c}\text { OLS } \\
\text { Reduced } \\
\text { Form for } Q\end{array}$} \\
\hline & \multicolumn{2}{|c|}{ Demand } & \multirow[b]{2}{*}{ Supply } & \\
\hline & $\begin{array}{l}(1) \\
\text { Including } \\
\text { Yields } \\
\end{array}$ & $\begin{array}{l}(2) \\
\text { Excluding } \\
\text { Yields }\end{array}$ & & \\
\hline Lagged hand-harvested cotton & $\begin{array}{c}0.63 \\
(10.61)\end{array}$ & $\begin{array}{c}0.66 \\
(9.80)\end{array}$ & $\begin{array}{c}0.23 \\
(3.43)\end{array}$ & $\begin{array}{c}0.71 \\
(17.15)\end{array}$ \\
\hline Labor compensation $(W)$ & $\begin{array}{l}-0.03 \\
(-0.05)\end{array}$ & $\begin{array}{c}-0.72 \\
(-1.07)\end{array}$ & $\begin{array}{c}0.19 \\
(0.69)\end{array}$ & \\
\hline Lagged cotton price $(P C T)$ & $\begin{array}{c}0.24 \\
(0.31)\end{array}$ & $\begin{array}{c}1.21 \\
(1.43)\end{array}$ & & $\begin{array}{c}0.53 \\
(1.81)\end{array}$ \\
\hline Machine-harvesting costs (MCOST) & $\begin{array}{c}1.59 \\
(7.20)\end{array}$ & $\begin{array}{c}1.36 \\
(5.49)\end{array}$ & & $\begin{array}{c}1.29 \\
(6.34)\end{array}$ \\
\hline Overhead costs of labor $(O V E R H)$ & $\begin{array}{c}-0.08 \\
(-0.59)\end{array}$ & $\begin{array}{c}0.07 \\
(0.47)\end{array}$ & & $\begin{array}{c}-0.03 \\
(-0.26)\end{array}$ \\
\hline Cotton allotment ( $A L L O T)$ & $\begin{array}{c}-0.02 \\
(-1.74)\end{array}$ & $\begin{array}{c}0.01 \\
(1.21)\end{array}$ & & $\begin{array}{c}-0.03 \\
(-3.37)\end{array}$ \\
\hline Soil bank dummy $(S O I L)$ & $\begin{array}{c}-0.20 \\
(-5.25)\end{array}$ & $\begin{array}{c}-0.17 \\
(-4.01)\end{array}$ & & $\begin{array}{c}-0.17 \\
(-4.31)\end{array}$ \\
\hline Nonagricultural wage rates $(W N O N)$ & & & $\begin{array}{c}-2.47 \\
(-1.39)\end{array}$ & $\begin{array}{c}0.34 \\
(0.50)\end{array}$ \\
\hline Cotton Yields $(Y)$ & $\begin{array}{c}0.83 \\
(6.98)\end{array}$ & & $\begin{array}{c}0.99 \\
(9.42)\end{array}$ & $\begin{array}{c}0.89 \\
(8.87)\end{array}$ \\
\hline Preharvest agricultural wage (PREHW) & & & $\begin{array}{c}-0.42 \\
(-0.79)\end{array}$ & $\begin{array}{c}0.21 \\
(0.69)\end{array}$ \\
\hline Planted cotton acreage (ACRES) & & & $\begin{array}{c}0.65 \\
(5.33)\end{array}$ & $\begin{array}{c}-0.03 \\
(-0.25)\end{array}$ \\
\hline State dummy variables $(S D)$ (Alabama or & itted) & & & \\
\hline Arkansas & $\begin{array}{c}0.32 \\
(1.67)\end{array}$ & $\begin{array}{c}0.61 \\
(2.89)\end{array}$ & $\begin{array}{c}-0.08 \\
(-0.94)\end{array}$ & $\begin{array}{c}0.22 \\
(1.63)\end{array}$ \\
\hline Georgia & $\begin{array}{l}-0.16 \\
(-1.83)\end{array}$ & $\begin{array}{l}-0.15 \\
(-1.46)\end{array}$ & $\begin{array}{l}-0.07 \\
(-0.84)\end{array}$ & $\begin{array}{l}-0.08 \\
(-0.54)\end{array}$ \\
\hline Louisiana & $\begin{array}{l}-0.11 \\
(-1.08)\end{array}$ & $\begin{array}{c}0.03 \\
(0.29)\end{array}$ & $\begin{array}{l}-0.07 \\
(-0.90)\end{array}$ & $\begin{array}{l}-0.017 \\
(-1.79)\end{array}$ \\
\hline Mississippi & $\begin{array}{c}0.45 \\
(4.25)\end{array}$ & $\begin{array}{c}0.57 \\
(4.81)\end{array}$ & $\begin{array}{l}-0.08 \\
(-1.01)\end{array}$ & $\begin{array}{c}0.38 \\
(2.20)\end{array}$ \\
\hline North Carolina & $\begin{array}{c}-0.31 \\
(-1.39)\end{array}$ & $\begin{array}{c}-0.09 \\
(-0.34)\end{array}$ & $\begin{array}{c}-0.09 \\
(-0.97)\end{array}$ & $\begin{array}{l}-0.022 \\
(-1.24)\end{array}$ \\
\hline South Carolina & $\begin{array}{l}-0.15 \\
(-1.81)\end{array}$ & $\begin{array}{c}-0.16 \\
(-1.69)\end{array}$ & $\begin{array}{c}-0.09 \\
(-1.05)\end{array}$ & $\begin{array}{c}-0.02 \\
(-0.16)\end{array}$ \\
\hline Tennessee & $\begin{array}{c}-0.12 \\
(-0.92)\end{array}$ & $\begin{array}{c}0.18 \\
(1.33)\end{array}$ & $\begin{array}{l}-0.02 \\
(-0.25)\end{array}$ & $\begin{array}{l}-0.18 \\
(-1.99)\end{array}$ \\
\hline Missouri & $\begin{array}{l}-0.22 \\
(-0.69)\end{array}$ & $\begin{array}{c}0.27 \\
(0.78)\end{array}$ & $\begin{array}{l}-0.11 \\
(-1.26)\end{array}$ & $\begin{array}{c}-0.32 \\
(-1.54)\end{array}$ \\
\hline Arizona & $\begin{array}{c}-0.09 \\
(-0.22)\end{array}$ & $\begin{array}{c}0.89 \\
(2.11)\end{array}$ & $\begin{array}{c}-0.22 \\
(-2.69)\end{array}$ & $\begin{array}{c}-0.44 \\
(-1.80)\end{array}$ \\
\hline California & $\begin{array}{c}-0.08 \\
(-0.23)\end{array}$ & $\begin{array}{c}0.85 \\
(2.22)\end{array}$ & $\begin{array}{c}-0.19 \\
(-2.32)\end{array}$ & $\begin{array}{c}-0.46 \\
(-1.94)\end{array}$ \\
\hline New México & $\begin{array}{c}-0.28 \\
(-1.09)\end{array}$ & $\begin{array}{c}0.30 \\
(1.09)\end{array}$ & $\begin{array}{l}-0.11 \\
(-1.37)\end{array}$ & $\begin{array}{c}-0.49 \\
(-1.85)\end{array}$ \\
\hline
\end{tabular}




\begin{tabular}{|c|c|c|c|c|}
\hline \multirow{3}{*}{$\begin{array}{l}\text { Method } \\
\text { Independent Variable }\end{array}$} & \multicolumn{3}{|c|}{ 2SLS Estimates of Structural Equations } & \multirow[t]{2}{*}{ OLS } \\
\hline & \multicolumn{2}{|c|}{ Demand } & \multirow[b]{3}{*}{ Supply } & \\
\hline & (1) & (2) & & \multirow[b]{2}{*}{$\begin{array}{l}\text { Reduced } \\
\text { Form for } Q\end{array}$} \\
\hline & $\begin{array}{l}\text { Including } \\
\text { Yields }\end{array}$ & $\begin{array}{l}\text { Excluding } \\
\text { Yields }\end{array}$ & & \\
\hline Intercept & -6.80 & -3.75 & -0.49 & -8.01 \\
\hline Adjusted $R^{2}$ & 0.95 & 0.94 & 0.48 & 0.95 \\
\hline$N \times T$ & 156 & 156 & 156 & 192 \\
\hline
\end{tabular}

Note: $t$-statistics are in parentheses.

The structural equation coefficients in Table 3 are short-run elasticities. ${ }^{68}$ In Table 4 we use the estimated coefficients to calculate the effect of each factor upon the demise of hand-harvested cotton, the dependent variable. ${ }^{69}$ As the fourth column of Table 4 shows, cheaper machine harvest costs caused a 5.72 percent annual decline in hand-harvested cotton, accounting for almost half of the of total yearly decline of 12.3 percent from 1952 to 1964 (right-hand column). ${ }^{70}$ The calculations in panels A and B are derived from first solving equations 1 and 2 for the endogenous variables. Then, we use the estimated parameters from the structural model (first three columns of Table 3), to measure the average annual change in $Q$ attributable to each. To illustrate our method, in the first row of Table 4, panel A, we find that real machine harvest costs fell by 4.14 percent per year. This technology shock introduced the greatest annual change among the determinants of the hand-harvest labor market-more than twice that of rising nonfarm wages. Cheaper harvest mechanization shifted the labor demand leftward by 6.57 percent on average each year ( -4.14 multiplied by the machine harvest cost coefficient of 1.587). Assuming no change in supply, falling machine harvest costs caused equilibrium wages to drop by 30 percent per annum and for the equilibrium quantity of cotton harvest labor employment to decline by 5.72 percent per year. $^{71}$

\footnotetext{
${ }^{68}$ The use of long- or short-run elasticities does not influence the effects of the exogenous variables presented in the following tables and text.

${ }^{69}$ We follow Peterson and Kislev's, "Cotton Harvester," method for analyzing the relative contribution of demand- and supply-side factors.

${ }^{70}$ Unlike Peterson and Kislev and Holley we quantify the variables' contribution to the total decline in picking cotton by hand. Note that for the two structural models three years of data are dropped, which does not occur in the reduced-form models: the annual fall in hand-harvest labor was 9.3 percent for the full 1949-1964 period.

${ }^{71}$ For Panels A and B of Table 4, we proceed as if $X$ stands for a generic exogenous variable of interest. The effect on the average annual change in $W$ of any change in $X$ will be $\frac{1}{\left(\hat{\alpha}_{1}-\hat{\beta}_{1}\right)}\left[-\gamma_{j} \dot{X}_{j}\right]$ where $X_{j}$ and $\gamma_{j}$ are the "jth" exogenous variable and coefficient from the structural estimates (the demand exogenous variables only will be preceded by a negative sign given the reduced form solution). The change in wages due to falling machine harvest costs is -6.57 multiplied by $(-1 /-0.03-0.19)$ which equals -29.97 . The change in $Q$ is then the change in wages multiplied by the
} 
Machine costs and the Soil Bank played the most important roles quantitatively, with cotton prices on the demand side and nonagricultural wage rates on the supply side appearing less important. Rising cotton yields worked in the opposite direction, off-setting some of the decline in demand and supply due to the other variables. For our purposes here, we would like to delineate the importance of each variable and then whether the net effects were mainly supply- or demand-driven.

First, we must address the differences between the estimates of demand functions 1 and 2 (Table 4, panels A and B). The second column of numbers in Table 4 shows that the shifts in demand differ somewhat between demand functions 1 and $2 .{ }^{72}$ Yet among the largest differences result from the transmission of those shifts to the endogenous variables (columns three and four). That means the variation in demand elasticities with respect to cotton harvest wages $(W)$ played a large role in the differences among the effects of exogenous variables on the dependent variables. Excluding yield from the demand function increases (in absolute value) the demand elasticity of labor compensation $(W)$ from -0.03 to -0.72 . Thus, with demand function 1 , changes in demand will generate larger effects on hand-harvested cotton but supply shifts will have lesser effects.

To help resolve which equation better represents the relative effects of the exogenous variables, we could use elasticities from other studies. ${ }^{73}$ A simple resolution of how the exogenous variables affect hand-harvested cotton entails the direct reduced form estimates (last column of Table 3). ${ }^{74}$ Aside from the advantage of simplicity, this approach allows the full time period of 16 rather than 13 years to be used, because the reduced form equation does not exhibit autocorrelation (Durbin's $h=0.280$ ). Thus, instrumental variable estimation based on lagged values of the predetermined variables becomes unnecessary, allowing retention of the three years that were dropped to estimate the structural model. Not only do we add information, but using the maximum number of years reduces the risk of small-sample bias, although all the estimators used here are consistent.

wage elasticity of supply (or times the wage elasticity of demand if a supply-side variable of interest). For machine harvest costs this is -29.97 times 0.19 which equals -5.72 percent per year.

${ }^{72}$ Machine costs are highly and negatively correlated with yields (coefficient $=-0.87$ ), so the latter's omission from the demand function may have biased the machine-cost coefficient toward zero in demand function 2 .

${ }^{73}$ It turns out that the supply elasticity is also sensitive to changes in specification, and the text value of 0.19 may be an underestimate. For example, if yield is omitted from supply, a statistically significant value of 1.44 results $(t=3.79)$. There is a risk, however, that omitted-variable bias leads to an overestimate of the supply elasticity in that case. Of course, this estimate results in an even greater effect of demand shifts on $Q$. We also used labor supply and demand elasticities from other studies; the results are similar to ours with respect to the relative effect of exogenous variables (Grove and Heinicke, "Better Opportunities" working paper).

${ }^{74}$ We thank an anonymous referee for this suggestion. 
TABLE 4

AVERAGE ANNUAL PERCENTAGE CHANGE IN QUANTITY OF LABOR EMPLOYED IN HAND HARVESTING ATTRIBUTABLE TO EXOGENOUS VARIABLES

\begin{tabular}{|c|c|c|c|c|c|}
\hline & \multicolumn{4}{|c|}{ Annual Average Percentage Change } & \multirow[b]{2}{*}{$\begin{array}{c}\text { Predicted Change } \\
\text { in Total Labor as } \\
\text { Percentage of } \\
\text { Actual }\end{array}$} \\
\hline & $\begin{array}{l}\text { Change in } \\
\text { Variable }\end{array}$ & $\begin{array}{l}\text { Shift in } \\
\text { Function }^{\mathrm{a}}\end{array}$ & $\begin{array}{l}\text { Change in } \\
\text { Wages }^{\mathrm{b}}\end{array}$ & $\begin{array}{l}\text { Change in } \\
\text { Quantity } \\
\text { of Labor }^{\mathrm{c}}\end{array}$ & \\
\hline \multicolumn{6}{|c|}{ Panel A: Based on Structural Model with Demand Function (1) } \\
\hline \multicolumn{6}{|l|}{ Demand } \\
\hline Real machine-harvesting costs & -4.14 & -6.57 & -29.97 & -5.72 & 47 \\
\hline Real cotton price & -1.96 & -0.46 & -2.12 & -0.41 & 3 \\
\hline Soil bank dummy & - & -20.10 & -91.65 & -17.49 & see note $\mathrm{d}$ \\
\hline Cotton yields & 3.35 & 2.78 & 12.67 & +2.42 & -20 \\
\hline \multicolumn{6}{|l|}{ Supply } \\
\hline Real nonagricultural wages & 1.65 & -4.07 & 18.56 & -0.46 & 4 \\
\hline Cotton yields & 3.35 & 3.30 & -15.07 & +0.43 & $-4^{\mathrm{e}}$ \\
\hline Predicted gross decrease & & & & -6.59 & $54^{\mathrm{f}}$ \\
\hline Predicted net change & & & & -3.74 & $30^{\mathrm{f}}$ \\
\hline \multicolumn{6}{|c|}{ Panel B: Based Structural model, with Demand Function (2) } \\
\hline \multicolumn{6}{|l|}{ Demand } \\
\hline Real machine-harvesting costs & -4.14 & -5.62 & -6.20 & -1.18 & 10 \\
\hline Real cotton price & -1.96 & -2.35 & -2.60 & -0.49 & 4 \\
\hline Soil bank dummy & - & -17.4 & -19.16 & -3.65 & see note $\mathrm{d}$ \\
\hline \multicolumn{6}{|l|}{ Supply } \\
\hline Real nonagricultural wages & 1.65 & -4.07 & 4.50 & -3.21 & 26 \\
\hline Cotton yields & 3.35 & 3.31 & -3.65 & +3.33 & $-27^{\mathrm{d}}$ \\
\hline Predicted gross decrease & & & & -4.88 & $40^{\mathrm{f}}$ \\
\hline Predicted net change & & & & -1.55 & $13^{\mathrm{f}}$ \\
\hline \multicolumn{6}{|c|}{ Panel C: Based Directly on Reduced-Form Estimates (coefficients from Table 3) } \\
\hline Real machine-harvesting costs & -4.04 & & & -5.21 & 56 \\
\hline Real cotton price & -1.60 & & & -0.85 & 9 \\
\hline Soil bank dummy & & & & -16.64 & see note $\mathrm{d}$ \\
\hline Cotton yields & 4.04 & & & +3.61 & -39 \\
\hline Real nonagricultural wages & 1.92 & & & +0.66 & -7 \\
\hline Predicted gross decrease & & & & -6.06 & $65^{\mathrm{g}}$ \\
\hline Predicted net change & & & & -1.79 & $19^{\mathrm{g}}$ \\
\hline \multicolumn{6}{|c|}{ Panel D: Based Directly on Reduced-Form Estimates (including year dummy variables) } \\
\hline Real machine-harvesting costs & -4.04 & & & -6.04 & 65 \\
\hline Real cotton price & -1.60 & & & -1.56 & 17 \\
\hline Soil bank dummy & & & & $-23.16^{\mathrm{h}}$ & see note $\mathrm{d}$ \\
\hline Cotton yields & 4.04 & & & +3.00 & -32 \\
\hline Real nonagricultural wages & 1.92 & & & +0.39 & -4 \\
\hline Predicted gross decrease & & & & -7.60 & $82^{g}$ \\
\hline Predicted net change & & & & -4.21 & $45^{\mathrm{g}}$ \\
\hline
\end{tabular}

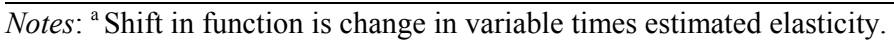

${ }^{\mathrm{b}}$ Reduced-form change in wages (due to variable) is shift in function times $\left[1 /\left(\alpha_{1}-\beta_{1}\right)\right]$.

${ }^{\mathrm{c}}$ Change in employment is change in wages times wage elasticity (of supply or demand).

${ }^{\mathrm{d}}$ Dummy variable denotes shift for years in question, and this is not comparable with annual average decrease. See the text.

${ }^{\mathrm{e}}$ Negative sign denotes this counteracts the decline in labor, i.e., is an increase. 
TABLE 4 - continued

${ }^{\mathrm{f}}$ Percentage explained not including the Soil Bank of actual annual average decrease of 12.3 percent.

${ }^{g}$ Percentage explained not including the Soil bank of actual annual average decrease of 9.3 percent

${ }^{\mathrm{h}}$ Lower bound on the Soil Bank effect $=$ Table entry +9.36 (see the text).

Panel C of Table 4 presents the results on $Q$ from the direct reduced form estimates. Panel D adds a complete set of time dummy variables for all years to guard against the possibility that the parameter estimates are not robust with respect to time-specific shocks. The reduced form estimates reveal some interesting conclusions. First of all, the structural model with yield included in the demand function (Table 4, Panel A) provides results most consistent with the reduced form estimates. Notably, machine costs and the Soil Bank dummy account for the greatest part of the decline in hand harvested cotton. Once time specific shocks are controlled for (Table 4, Panel D, regression coefficients available upon request), cotton prices play an important role in the decrease in cotton harvest employment $(Q)$. Thus, previous studies appear to have underestimated the role of labor demand in decreasing harvest employment.

The price of cotton did not affect all producers equally, in the sense that technological change itself in the western part of the cotton belt increased supply, and put more pressure on eastern producers. ${ }^{75}$ Still this period was one of sustained pressure on producers from abroad and from synthetic fibers. The effect of the Soil Bank was quite large. Referring to the reduced form estimates, we see that, controlling for other variables, the Soil Bank years saw a rate of decrease in hand-harvested cotton of more the one-andone-half times the average year. Surprisingly, the reduced form indicates a minor role for nonagricultural wages (as with the estimates from the structural model with yield included in the demand function).

The structural model's decomposition in Table 4 implies that the minimal effect of nonagricultural wages could result from the very small elasticity of demand in equation $1 .^{76}$ In addition, multicollinearity may partly obscure some of the effect of nonagricultural wages and account for the incorrect sign in the reduced form estimates (the correlation coefficient between yields and

\footnotetext{
${ }^{75}$ Heinicke and Grove, "Labor Markets."

${ }^{76}$ Given the possibility that the structural demand and supply elasticities were subject to bias, we also used estimated elasticities for southern hired farm labor from contemporary studies (see Tyrchniewicz and Schuh, "Regional Supply"; and Schuh and Leeds, "Regional Demand") to compute our decomposition (using our own estimates for the other coefficients). The results were similar to what we find here with respect to relative effects: mechanization accounted for 32 percent of the decrease in hand-harvested labor, cotton prices for 13 percent, and nonagricultural wages, 10 percent, whereas the Soil Bank years showed a decrease in the quantity of hand-harvested cotton that was more than twice that of the average annual decrease (results available in a working paper, Grove and Heinicke, "Better Opportunities").
} 
nonagricultural wages is 0.79$).{ }^{77}$ We also estimated the reduced form limited to the 13 years used in the structural estimates (not reported here) in the hope that multicollinearity would be reduced and the effect of nonagricultural wages would be measured more completely; nonagricultural wage rates account for 14 percent of the annual decrease in that version. ${ }^{78}$ On balance, then, labor-demand variables, not labor-supply factors, predominantly explain the decline in hand-harvested cotton. ${ }^{79}$

\section{MEASUREMENT AND OTHER SPECIFICATION ISSUES}

Consideration of alternative specifications leave our central findings intact.$^{80}$ For example, the allotment effect remains essentially the same whether measured with a dummy variable for the years in effect or with actual allotted acreage. Including dummies for each year controls for time-period shocks, such as the business cycle or the Korean war. Might a dummy variable for the Soil Bank years actually be measuring other shocks during those years? We estimated the reduced form model with time dummies for each year except for 1956-1958 and 1964, which were consolidated into a single dummy variable. Then, we re-estimated the model four times including a separate dummy for each year, 1956, 1957, 1958, and 1964, in successive regressions. Effects larger than the four-year average occurred in 1957 (negatively) and 1958 (positively) ${ }^{81}$ Because the 1957 (relative to four-year average) dummy was negative, it would appear that a lower bound (in absolute value) on the Soil Bank's effect would be the dummy variable for the four years with the 1957 dummy also included, i.e. the dummy for the Soil Bank

\footnotetext{
${ }^{77}$ No obvious explanation can be given for this empirical correlation, other than that the crosssectional variation may be important. The western states had the highest cotton yields, and also, California possessed the highest nonagricultural wages. Note that dropping yields would be not only unwise (due to its importance theoretically and empirically) but the positive bias imparted would act to further obscure the measurement of the effect of nonagricultural wages.

${ }^{78}$ Our study includes a measure of overhead costs of organizing the harvest separately in the regression (as workers did not receive this as compensation). If such costs increase, growers may substitute toward machines, even though workers receive no increased compensation. The magnitude of these effects were small in our results, and the sign of the coefficient varied according to specification (see Table 3). The positive sign in demand 2 may be due to omitted-variable bias (yields were correlated with overhead costs). In one version that includes time dummies for each year, the effect was nontrivial, accounting for 15 percent of the annual decrease in hand-harvested cotton. This variable does not fit into the "push" versus "pull" dichotomy often used, but could have been an important impetus to reduce hand harvesting of cotton.

${ }^{79}$ Despite the temporary nature of the Soil Bank, the effects could have lowered income below a threshold, inducing permanent out-migration. Burford, "Federal Cotton," reaches conclusions similar to ours, although he does not separate the Soil Bank effects.

${ }^{80}$ The coefficient measuring the effect of machine prices is very stable and highly significant in every specification we attempted. We estimated several specifications with varying lags on the predetermined variables in the reduced form, none of which altered the central findings here (available upon request).

${ }^{81}$ The coefficients were $-0.010,-0.094,+0.13$, and +0.013 with $t$-statistics of $-0.13,-1.51,+1.83$, and -0.11 , respectively.
} 
years removing the greater than average negative effect from among the four years. Such a lower-bound estimate suggests that in the Soil Bank years, controlling for the other variables, hand-harvested cotton decreased by -13.80 percent, or about 148 percent of the 1949-1964 average annual decrease. ${ }^{82}$ Econometrically, we have shown that something common to the four years caused this large negative effect; in the absence of any other obvious candidate, we expect that we have found the culprit in the Soil Bank. ${ }^{83}$ In light of the importance of the Soil Bank, however, the negligible effect of decreasing cotton allotments on harvest labor demand is curious. Perhaps the explanation is that the reinstitution of the allotment program in 1950-a one time shock - was more important than any year-to-year variation in allotted acreage.

Finally, we should comment on the presumed exogeneity of government agricultural programs, especially in light of the powerful cross-over lobbies of farm and southern interests. ${ }^{84}$ Although government crop programs were endogenous in a long-run sense, the year-to-year decisions that affected the harvest labor market were normally made once the contours of a particular program were well known. We do not think that changes in year-to-year quantities or wages affected those government programs within a time frame that would render bias in our estimates of their effects. Therefore, we think it makes sense to measure these programs as exogenous to the yearly cotton harvest labor market. ${ }^{85}$

Although the results are not completely impervious to specification changes, our basic conclusions, as summarized in Table 4, remain unaltered. Next, we turn to a comparison of our results and the best empirical estimates to date.

\section{COMPARISON WITH OTHER ESTIMATES}

First, we offer a point of clarification and then an explanation of the four factors that we perceive to account for the differences between our conclusions and Peterson and Kislev's that "79 percent of the reduction in hand picking of cotton was due to increased nonfarm wages - the pull effect; the

\footnotetext{
${ }^{82}$ As noted at the bottom of Table 4, the dummy variable measures a discrete effect and so is not directly comparable with an annual average; we simply illustrate the magnitudes here.

${ }^{83} 1957 / 58$ and 1964 were recessionary years, but the downturn was not seen until late summer 1957, and by April of 1958 an economic recovery was in evidence. Finally, the unemployment rate in 1961 was 6.7 percent, nearly that of the high of 1958 of 6.8 percent. Yet the time dummy variables do not show a negative effect in 1960 or 1961 equal to the Soil Bank years.

${ }^{84}$ Alston and Ferrie, Southern Paternalism.

${ }^{85}$ This may have been less the case in the 1930s when a high proportion of tenancy made manipulation of payments an important factor in the year's income (see Whatley, "Labor"). By 1956 tenancy had been drastically reduced in much of the cotton belt. Also, changes in labor scarcity are too removed from enactment of the Soil Bank for there to have been a very large feedback with respect to that particular program.
} 
remaining 21 percent is attributable to the decreased cost of machine harvesting-the push effect." 86 To begin with, Peterson and Kislev do not calculate the percentage of the net labor force decline caused by each variable, as we have done (and are unable to do from their paper); instead, they compare the effect of either industrial wages or machine displacement to the combined shifts. ${ }^{87}$ To illustrate, see Table 4, Panel B, where we replicate Peterson and Kislev's specification which includes yields only in the supply function and obtain results comparable to theirs of three-quarters nonagricultural wage "pull" versus one-quarter mechanization "push." As Panel B makes clear, although the manufacturing wage effect exceeded that of cheaper harvest machines, industrial wages explained no more than a quarter of the disappearance of hand-picked cotton.

The different explanations for the demise of hand-harvested cotton result, first and most generally, from the framework of analysis: our question is to determine the relative role of each factor involved, whereas Peterson and Kislev's and Holley's head-to-head comparisons of two important determinants are silent on the effects of government acreage-reduction programs and cotton prices in this episode of structural change. Secondly, discrepancies between our conclusions and those of Peterson and Kislev and Holley result from their unusual specifications, which include yields only in the supply functions. ${ }^{88}$

The third and fourth reasons our estimates of shifts in demand and supply differ from Peterson and Kislev's result from the data used and the time period analyzed. Peterson and Kislev use piece rates, which omit: the expense of overhead costs, nonpecuniary transfers to harvest laborers, and the gin turnout rate; the national manufacturing wage, whereas we construct a combined in-state and out-of-state entry-level industrial wage; and custom harvest costs. ${ }^{89}$ Regarding the latter, despite the fact that commercial production of cotton-picking machines only began in 1948, Peterson and Kislev examine the 1930-1964 period..$^{90}$ They estimated 1930 cotton-harvest custom rates by assuming that the ratio of cotton-harvesting custom rates to

\footnotetext{
${ }^{86}$ Peterson and Kislev, "Cotton Harvester," p. 199.

${ }^{87}$ Peterson and Kislev, "Cotton Harvester."

${ }^{88}$ As noted previously, omitting yields in the demand function biases the coefficient on machine costs toward zero, probably accounting for some of Peterson and Kislev's and Holley's underestimate of the effect of mechanization.

${ }^{89}$ The gin turnout rate is the ratio of raw cotton picked in the field, the basis on which growers pay piece rates, to cotton lint, from which growers earn their income.

${ }^{90}$ They base this assumption on the claim that the Rust brothers' 1930s picking machine was fundamentally the same design as the successful commercial models marketed two decades later. These arguments fail to recognize that substantial design changes occurred by 1942 and that every aspect of its design and operation were tinkered with extensively and adapted to local microclimates from California to the Carolinas with a full complement of production practices resulting from a massive, long-term public-private research effort (Grove, "Economics"). Note that in the working-paper version of their project Peterson and Kislev examined the 1949-1964 period and used Meier's machine harvest cost data.
} 
wheat-harvesting rates remained the same from 1930 to 1949 and then calculated the 1931-1948 time series for all 12 states by assuming that the cotton-harvest custom rates increased with the change in the USDA machine-price index. The authors offer no evidence to confirm that their constructed custom rates reflect prices that farmers faced from 1931 to 1948. As Warren Whatley discussed at length, even the custom-rate estimates for the 1949 to 1964 period are highly suspect. ${ }^{91}$ Donald Holley replicated Peterson and Kislev's framework but used the same time period we do and machine-harvest costs instead of custom rates; his results lie between ours and those of Peterson and Kislev. ${ }^{92}$

Finally, perhaps Peterson and Kislev's estimates apply more to the pre1949 period, especially the World War II years, when labor scarcity became the rule in the cotton fields and the urban-farm wage gap exerted greater influence. ${ }^{93}$ Although a typical grower could not adopt the mechanical picker before 1948 and very little custom harvesting occurred, higher wages outside of agriculture no doubt signaled current and perhaps future labor scarcity, leading to intensified demands for a manageable substitute for hand pickers. ${ }^{94}$ Our results, by contrast, reflect the period when mechanization and government acreage-reduction programs provided the main causes for the demise of cotton hand-harvest labor.

\section{CONCLUSIONS AND IMPLICATIONS}

Although the implications of the demise of hand harvested cotton have been linked to several seminal developments in the late twentieth century, namely the decline of America's cities, changes in race relations and racial economic equality, and the rise of the welfare state, its causes have not been carefully estimated. Peterson and Kislev and Holley attributed the labor exodus predominantly to higher industrial wages rather than mechanization,

\footnotetext{
${ }^{91}$ Whatley, in "New Estimates," pp. 217-20, levels two principal criticisms. First, only Arizona published custom cotton harvest rates for the 1949-1964 period. Peterson and Kislev assumed a fixed ratio of these costs to those in other states based on four individual observations. Secondly, the machine rental rates fail to include indirect grade and field losses, which, when incorporated, imply mechanization would not have occurred. The variability of grade losses by region and of the progress in techniques to address such problems lead one to question Peterson and Kislev's assumptions.

${ }_{92}$ Although Holley writes that he uses "custom rates" obtained from Whatley, "New Estimates," we think he actually used the Meier machine harvest cost data that Whatley corrected. Holley finds that mechanization accounts for 40 percent and nonagricultural wage rates 60 percent of the harvest labor decrease (p. 175). Data differences include Holley's use of piece rates for hand-picking costs, national manufacturing wages instead of our nonagricultural wages, unadjusted machine costs, and no measure of the role of government acreage reduction programs. In terms of the causes of decreased employment, he considers only harvester displacement and manufacturing wage pull.

${ }^{93}$ That is also consistent with Day's, "Economics," finding that labor abundance appeared after 1950 in the Mississippi Delta. See also Street, "New Revolution"; Whatley, "History" and "Southern Agrarian Labor Contracts"; and Wright, Old South.

${ }^{94}$ We thank an anonymous referee for this point.
} 
although their results do not square with the fact that real harvest wages declined over the period. We estimate the role of relative supply and demand shifts for hand-harvest labor in the 12 major cotton-picking states from 1949 to 1964 and conclude that, on net, labor-demand, not labor-supply factors ended the age of labor-intensive cotton production.

We make three main contributions in this article. First, we use newly reconstructed data on hand harvest costs as well as improved measures of machine picking expenses and nonagricultural wage rates. Second, we broaden the scope of analysis by evaluating the effect of all important variables, not, as the existing empirical studies have, by comparing only the relative effects of cheaper picking machines and higher industrial wages. Finally, we offer the first estimates of how much of the total decrease in hand-harvest labor each variable explains.

We find that declining machine costs accounted for one-half or more of the decrease in hand-harvested cotton. Controlling for mechanization and other variables, during the four years the federal government Soil Bank program operated, hand-harvested cotton declined by more than one-andone-half times the average annual total. Cotton prices also added to the demise of hand picking, ranging from 3 to 21 percent of the annual average decrease. Although data problems partially obscured their measurement, the decrease in labor supply due to nonagricultural wages accounted for up to 26 percent of the annual average decline in hand-harvested cotton. Although we reverse Peterson and Kislev's emphasis on the manufacturing wage, most importantly we broaden the scope of analysis. Our results indicate that the machine-push-versus-factory-pull dichotomy ignores the important roles played by cotton prices and government programs to reduce cotton acreage.

Whereas Peterson and Kislev's findings exonerated the relevant public and private entities that promoted and subsidized harvest mechanization because their results suggested that workers left the cotton fields for better opportunities elsewhere, our results imply the opposite public-policy consequences. Federal and state governments assisted growers in the transition to completely mechanized production but offered virtually no adjustment assistance to displaced workers as has occurred for trade-displaced workers for decades. ${ }^{95}$ Negative shifts in labor demand resulted, either fully or partially, from government policies, with both intended (i.e., the cotton harvest mechanization program) and unintended consequences (i.e., Soil Bank). It should be borne in mind that this is not a migration model; if workers left the cottonharvest labor market because of a decrease in labor demand we cannot say if they stayed in the cotton states permanently, for a period of some years, or migrated immediately. Many nonmigrants may have fared poorly as the old

\footnotetext{
${ }^{95}$ Kletzer, Job Loss. Day, “Economics,” for example, expressed concern that the mechanical cotton picker might simply exchange rural poverty for urban poverty.
} 
cotton belt contains some of the greatest pockets of American rural poverty today. ${ }^{96}$ The least-able being left behind is consistent with a strong "push" out of the fields, at the same time that migration continued to select those with the greatest earning power among southern African-Americans. In that sense our findings are also consistent with an emerging view that migrants rarely moved directly "from farm-to-factory.",97

Our evidence links the demise of cotton harvest labor markets to several seminal developments in the late twentieth century: incentives for preserving the Old South system of social control, changes in racial economic equality, and the decline of America's cities. For contemporaries in 1946, it was unclear that a way of life in the South in place for generations would crumble and disappear in two decades. ${ }^{98}$ Technological displacement appears to have improved black progress in the long term since mechanization reduced the incentive of southern political interests to maintain a system of social control and to block both Civil Rights legislation and enforcement. ${ }^{99}$

Given that the movement of labor out of agriculture has proven to be a classic feature of economic development, this historical analysis may provide insights for the vast majority of countries around the world with large farm populations. Recently, for instance, harvest mechanization in Brazil's sugar industry led to an unprecedented rate of migration by cane cutters and their families to large cities. ${ }^{100}$ Most of the world's major cotton-producing countries, namely China, India, Pakistan, and Uzbekistan, gather the crop entirely by hand. ${ }^{101}$ The agricultural transformation examined here stands as an extraordinary example of the pain and promise associated with long-run economic development that looms somewhere in the future for the world's 100 million cotton workers.

\footnotetext{
${ }^{96}$ Heinicke, "One Step."

${ }^{97}$ Collins, “African-American Economic Mobility,” p. 765.

${ }^{98}$ Wright, "Civil Rights." Farm-sector predictions of yields and rates of mechanization in 1950 to 1955 vastly underestimated the pace of those changes (Grove, "Economics"). See Wright, "Civil Rights Revolution," for a discussion of the unexpected speed of the Civil Rights movement. Public opinion regarding integrated education, for example, did change rapidly. In 1963, 60 percent of white southerners objected to school integration compared to only 16 percent in 1970. "This finding," commented George Gallup, "represents one of the most dramatic shifts in the history of public opinion polling " (Burton, "Race Relations," p. 44).

${ }^{99}$ Alston and Ferrie, "Paternalism."

${ }^{100}$ See Simon Romero's article in the Sunday 21 May 2000 The New York Times entitled "Spoonfuls of Hope, Tons of Pain: In Brazil's Sugar Empire, Workers Struggle with Mechanization," Section 3, page 1 .

${ }^{101}$ Note the interesting example of Uzbekistan where complete mechanization under the Soviet regime reverted to hand harvesting with the collapse of the USSR (see Pomfret, Agrarian Reform).
} 


\section{REFERENCES}

Alston, Lee J., and Joseph P. Ferrie. "Paternalism in Agricultural Labor Contracts in the U.S. South: Implications for the Growth of the Welfare State." American Economic Review 83, no. 4 (1993): 852-76.

. Southern Paternalism and the American Welfare State. New York: Cambridge University Press, 1999.

Arkansas Department of Labor. Arkansas Farm Labor Reports. Fayetteville, AR, 19501960.

Arizona State Employment Service. Arizona Farm Labor Report. Phoenix, AZ: Employment Security Commission: 1950-1960.

Blanchard, Olivier Jean, and Lawrence Katz. "Regional Evolutions." Brookings Papers on Economic Activity 1992, no.1 (1992): 1-75.

Bowles, Samuel, Herbert Gintis, and Melissa Osborne. Journal of Economic Literature 39, no. 4 (2001): 1137-76.

Burford, Roger L. "The Federal Cotton Programs and Farm Labor Force Adjustments." Southern Journal of Economics 33, no. 2 (1966): 223-36.

Burton, Orville Vernon. "Race Relation in the Rural South Since 1945." In The Rural South Since World War II, edited by R. Douglas Hurt. Baton Rouge: Louisiana State University, 1998.

California Department of Employment. “California Weekly Farm Labor Report.” Research and Statistics, 1949-1960.

Capstick, Daniel F. “Economics of Mechanical Cotton Harvesting.” Arkansas Agricultural Experiment Station Bulletin 622, 1960.

Carrington, William J., Enrica Detragiache, and Tara Vishwanath. "Migration with Endogenous Moving Costs." American Economic Review 86, no. 4 (1996): 909-30.

Christinsen, Raymond P., and Ronald O. Aines. "Economic Effects of Acreage Control Programs in the 1950s." Washington, DC: USDA, ERS, Agricultural Economic Report 18 (1962).

Cobb, James C. The Most Southern Place on Earth: The Mississippi Delta and the Roots of Regional Identity. New York: Oxford University Press, 1994.

Cochrane, Willard C., and Mary E. Ryan. American Farm Policy. Minneapolis: University of Minnesota Press, 1976.

Cogan, John. "The Decline in Black Teenage Employment 1950-1960." American Economic Review 72, no. 4 (1982): 620-37.

Collins, William. J. "When the Tide Turned: Immigration and the Delay of the Great Black Migration.” This JOURNAL 57, no. 3 (1997): 607-32.

. "African-American Economic Mobility in the 1940s: A Portrait from the Palmer Survey." This JOURNAL 60, no.3 (2000): 756-81.

Committee for Economic Development. An Adaptive Program for Agriculture. NY: Committee for Economic Development, 1962.

Cunningham, Firman Lytle. "An Analysis of the Development, Operation, and Economic Significance of the Farm Labor Market in Memphis, Tennessee." Ph.D. diss., Vanderbilt University, 1963.

Curtis, Cable, Jr. A Chronology of Government Programs for American Upland Cotton. Fayetteville: Arkansas Agricultural Experiment Station April 1957.

Cutler, David M., Glaeser, Edward L., and Jacob L. Vigdor. "The Rise and Decline of the American Ghetto.” Journal of Political Economy 107, no. 3 (1999): 455-506.

Daniel, Pete. Breaking the Land: The Transformation of Cotton, Tobacco, and Rice Cultures since 1880. Urbana: University of Illinois Press, 1985. 
Day, Richard. "The Economics of Technological Change and the Demise of the Sharecropper." American Economic Review 57, no. 3 (1967): 427-49.

Dawson, George R. "Preliminary Investigation of Farm Labor Conditions in New Mexico." New Mexico Agricultural Experiment Station, 1961.

DeCanio, Stephen. Agriculture in the Postbellum South: The Economics of Production and Supply. Cambridge, MA: MIT Press, 1974.

Dillingham, Harry C., and David F. Sly ."The Mechanical Cotton-Picker, Negro Migration, and the Integration Movement." Human Organization 25, no. 4 (Winter 1966): $344-51$.

Donohue, John J., and James Heckman. "Continuous Versus Episodic Change: The Impact of Civil Rights Policy on the Economic Status of Blacks." Journal of Economic Literature 29, no. 4 (1991): 1603-43.

Dunbar, Paul A. Our Land Too. New York: Vintage Books, 1972.

Eldridge, Hope T., and Simon S. Kuznets. Population Redistribution and Economic Growth 1870-1950. Vol. 3, Demographic Analyses and Interrelations, vol. 3. Philadelphia: American Philosophical Society, 1964.

Fair, Ray. "The Estimation of Simultaneous Equations Models with Lagged Endogenous Variables and First Order Autocorrelated Errors." Econometrica 38, no. 3 (1970): $507-16$.

Fairlie Robert W., and William A. Sundstrom. "The Emergence, Persistence, and Recent Widening of the Racial Unemployment Gap." Industrial and Labor Relations Review 52, no. 2 (1999): 252-70.

Fite, Gilbert. Cotton Fields No More. Lexington: University of Kentucky Press, 1984.

Fligstein, Neil. Going North: The Migration of Blacks and Whites from the South, 1900-1950. New York: Academic Press, 1981.

Fogel, Robert W. The Fourth Great Awakening and the Future of Egalitarianism. Chicago: The University of Chicago Press, 2000.

Fusfeld, Daniel R., and Timothy M. Bates. The Political Economy of the Urban Ghetto. Carbondale and Edwardsville: Southern Illinois University Press, 1984.

Gill, Flora. Economics and the Black Exodus: An Analysis of Negro Emigration from the Southern U.S. 1910-70. New York: Garland Publishing, 1979.

Goldin, Claudia, and Robert Margo. "The Great Compression: The Wage Structure in the United States at Mid-Century." Quarterly Journal of Economics 107, no. 1 (1992): $1-34$.

Greene, William H. Econometric Analysis. New York: Prentice Hall, 1997.

Grove, Wayne A. "The Mexican Farm Labor Program, 1942-64: Government Administered Labor Market Insurance for Farmers." Agricultural History 70, no. 2 (1996): 302-20.

. "The Economics of Cotton Harvest Mechanization in the United States, 1920-1970.” Ph.D. diss., University of Illinois Urbana-Champaign, 2000.

. "The Logic of the Southern Tenant Plantation in the Twentieth Century: Weather and Regional Labor Market Arrangement in U.S. Cotton Production: 1900-1945." Manuscript, 2002.

Grove, Wayne A., and Craig Heinicke. "Better Opportunities or Worse?: The Demise of Harvest Labor, 1949-64.” Management Division Working Paper, LeMoyne College, 2002.

Halberstam, David. The Fifties. NY: Villard Books, 1993.

Heckman, James. "The Central Role of the South in Accounting for the Economic Progress of Black Americans." American Economic Review 80, no. 2 (1990): 242-46.

Heinicke, C. "African American Migration and Mechanized Cotton Harvesting in the 
1950s." Explorations in Economic History 31, no. 4 (1994): 501-20.

. "Black Migration From the Rural American South and Mechanization in Agriculture, 1960-1960.” Ph.D. diss., University of Toronto, 1991.

. "The Federal Soil Bank, the Decline of Cotton, and the Demise of the Southern Plantation in the 1950s." Paper presented at the Cliometrics meetings of the Allied Social Sciences Association. New Orleans, January 1997.

. "Southern Tenancy, Machines and Production Scale on the Eve of the Cotton Picker's Arrival." Social Science History 23, no. 3 (1999): 435-58.

. "One Step Forward: African-American Married Women in the South, 1950-60." Journal of Interdisciplinary History 31, no. 1 (2000): 43-62.

Heinicke, Craig, and Wayne A. Grove. "Labor Markets, Regional Diversity, and Cotton Harvest Mechanization in the Post-WWII United States." Social Science History (forthcoming).

Holley, Donald. The Second Great Emancipation: The Mechanical Cotton Picker, Black Migration, and How They Shaped the Modern South. Fayetteville: The University of Arkansas Press, 2000.

Im, K. S., M. H. Pesaran, and Y. Shin. "Test for Unit Roots in Heterogeneous Panels." Working Paper, University of Cambridge Economics, 1997.

Johnson, Daniel M., and Rex R. Campbell. Black Migration in America. Durham, NC: Duke University Press, 1981.

Kirby, Jack T. Rural Worlds Lost: The American South 1920-1960. Baton Rouge, LA: Louisiana State University Press, 1987.

Lemann, Nicholas. The Promised Land: The Great Black Migration and How it Changed America. New York: Vintage Books, 1992.

LeRoy, Nelson, and Grady B. Crowe. "Labor and Technology on Selected Cotton Plantations in the Delta Area of Mississippi, 1953-57." Mississippi Agricultural Experiment Station, Bulletin no. 575 (1959).

King, George and Associates. "Goin' to Chicago.” University of Mississippi Center for the Study of Southern Culture and Afro-American Studies Program. San Francisco, CA, California Newsreel, 1994.

Kletzer, Lori G. Job Loss from Imports: Measuring the Costs. Washington, DC: Institute for International Economics, 2001.

Maddox, James G. "Private and Social Costs of the Movement of People Out of Agriculture." American Economic Review 50, no. 2 (1960): 392-402.

Maloney, Thomas N. "Wage Compression and Wage Inequality Between Black and White Males in the United States, 1940-1960." This JOURNAL 54, no. 2 (1994): 358-81.

Mansfield, Edwin. The Economics of Technological Change. New York: W.W. Norton, 1968.

Margo, Robert A. Race and Schooling in the South 1880-1950. Chicago: University of Chicago Press, 1990.

. "Explaining Black-White Wage Convergence, 1940-50." Industrial and Labor Relations Review 48, no. 3 (1995): 470-81.

Margo, Robert A., and T. Aldrich Finegan. "The Decline in Black Teenage Labor Force Participation in the South 1900-70: The Role of Schooling." American Economic Review 83, no. 1 (1993): 234-47.

Masters, Stanley H. Black-White Income Differentials: Empirical Studies and Policy Implications. New York: Academic Press, 1975.

Martin, Marshall A., and Joseph Havlicek Jr. "Some Welfare Implications of the Adoption of Mechanical Cotton Harvesters in the United States." American Journal of Agricultural Economics 59, no. 4 (November 1977): 739-44. 
Meier, Frank. "An Economic Analysis of Adoption of the Mechanical Cotton Picker." Ph.D. diss., University of Chicago, 1969.

Musoke, Moses S., and Alan L. Olmstead. "The Rise of the Cotton Industry in California: A Comparative Perspective.” This Journal 42, no. 2 (1982): 385-412.

Nerlove, Marc. The Dynamics of Supply: Estimation of Farmer's Response to Price. Baltimore: Johns Hopkins Press, 1958.

New Mexico State Employment Service. New Mexico Farm Placement Program: Annual Report.1950-1960.

Pederson, Harold A., and Arthur F. Raper. "The Cotton Plantation in Transition." Mississippi Agricultural Experiment Station Bulletin no. 508 (1954).

Peterson, Willis, and Yoav Kislev. "The Cotton Harvester in Retrospect: Labor Displacement or Replacement?" This JouRnAL 46, no. 1 (1986): 199-216.

. "The Cotton Harvester in Retrospect: Labor Displacement or Replacement?" Staff Paper P81-25, Department of Agricultural and Applied Economics, University of Minnesota, September 1981.

Piven, Frances Fox, and Richard A. Cloward. Regulating the Poor: The Functions of Public Welfare. New York: Vintage Books, 1971.

Pomfret, Richard. "Agrarian Reform in Uzbekistan: Why the Chinese Model failed to Deliver?" Economic Development and Cultural Change 48, no. 2 (2000): 269-84.

Ruggles, Steven, Matthew Sobek, et al. Integrated Public Use Microdata Series (IPUMS): Version 2.0 Minneapolis: Historical Census Projects. University of Minnesota, website: http://www.ipums.umn.edu. 1997.

Schuh, G. Edward, and John Leeds. "Regional Demand for Hired Agricultural Labor." Papers and Proceedings of the Regional Science Association 11, no. 31 (1963): 295-308.

Schultz, Theodore W. "The Value of the Ability to Deal with Disequilibria." Journal of Economic Literature 13, no. 3 (1975): 827-46.

Smith, James P., and Finis R. Welch. "Black Economic Progress After Myrdal." Journal of Economic Literature 27, no. 2 (1989): 519-64.

Street, James H. "The 'Labor Vacuum' and Cotton Mechanization." Journal of Farm Economics 35, no. 3 (1953): 381-97.

. The New Revolution in the Cotton Economy. Chapel Hill: The University of North Carolina Press, 1957.

Sugrue, Thomas J. The Origins of the Urban Crisis: Race and Inequality in Postwar Detroit. Princeton, NJ: Princeton University Press, 1996.

Taylor, J. Edward, and Philip L. Martin. "Human Capital: Migration and Rural Population Change" In Handbook of Agricultural Economics, edited by Bruce L. Gardner and Gordon C. Rausser, NY: Elsevier Science, forthcoming.

Tyrchniewicz, Edward, and G. Edward Schuh. "Regional Supply of Hired Labor in Agriculture." Journal of Farm Economics 48, no. 3 (1966): 537-56.

U.S. Bureau of the Census. Seventeenth Census of the United States, 1950. Washington, DC: GPO, 1952.

. Census of Population, 1960. Washington, DC: GPO, 1962.

. 1970 Census of Population. Washington, DC: GPO, 1972.

Historical Statistics of the United States, Colonial Times to 1970. Washington, DC: GPO 1975.

U.S. Department of Agriculture. "Preliminary Survey of Major Areas Requiring Outside Agricultural Labor." Extension Farm Labor Circular 38, 1947.

. Production and Marketing Administration, Cotton Branch. Charges for Ginning Cotton. Washington, DC: GPO, 1955-1966. 
. "Changes in Farm Productivity and Efficiency." Statistical Bulletin No. 233, August 1961.

. Agricultural Research Service. "The Conservation Reserve Program of the Soil

Bank, Effects in Selected Areas, 1957.” Agriculture Information Bulletin No. 185, March 1958.

. Cotton Allotment Data. 1975.

_. Statistical Reporting Service, Crop Reporting Board. Farm Labor. 10 November 1964.

. Statistics on Cotton and Related Data 1920-1973. Washington, DC: GPO, 1974.

U.S. Department of Commerce. Historical Statistics of the United States, Colonial Times to 1957. Bureau of the Census. Washington, DC: GPO, 1957.

. The Social and Economic Status of the Black Population in the United States. Bureau of the Census. Washington, DC: GPO, 1972.

U.S. Department of Labor. "Cotton Harvest Mechanization: Effect on Seasonal Hired Labor.” Bureau of Employment Security, BES No. 209. Washington, DC: GPO, 1962. . Farm Labor Market Developments. 1957-1959.

U.S. House Committee on Agriculture. Study of Agricultural and Economic Problems of the Cotton Belt. Hearings before the Special Subcommittee on Cotton, House of Representatives, 80th Congress, 1st Session, Part 1, 7 and 8 July; Part 2, 10 October 1947. Washington: GPO, 1947.

Vickery, William. The Economics of Negro Migration 1900-1960. New York: Arno Press, 1969.

Walton, Anthony. "Technology versus African-Americans." Atlantic Monthly 283 (January 1999): 17.

Whatley, Warren C. "A History of Mechanization in the Cotton South: Institutional Hypothesis." Quarterly Journal of Economics 100, no. 4 (1985): 1191-215.

. "Labor for the Picking: The New Deal in the South." This Journal 43, no. 4 (1983): 905-29.

."Southern Agrarian Labor Contracts as Impediments to Cotton Mechanization." This JOURNAL 46, no. 1 (1987): 45-70.

. "New Estimates of the Cost of Harvesting Cotton: 1949-1964." Research in Economic History 13 (1991): 199-225.

Williamson, Jeffrey G., and Peter H. Lindert. American Inequality: A Macroeconomic History. New York: Academic Press, 1980.

Wilson, William Julius. The Truly Disadvantaged. Chicago: University of Chicago Press, 1987.

Wright, Gavin. "The Civil Rights Revolution as Economic History." This Journal 59, no. 2 (1999): 267-89.

. Old South, New South. New York: Basic Books, 1986.

. "The Economic Revolution in the American South." Journal of Economic Perspectives 1, no. 1 (1987): 161-78. 